\title{
SIMULATION OF GROUND-WATER FLOW AND \\ WATER-LEVEL DECLINES THAT COULD BE CAUSED BY \\ PROPOSED WITHDRAWALS, NAVAJO SANDSTONE, SOUTHWESTERN UTAH AND NORTHWESTERN ARIZONA
}

By Victor M. Heilweil and Geoffrey W. Freethey

U.S. GEOLOGICAL SURVEY

Water-Resources Investigations Report 90-4105

Prepared in cooperation with the

NATIONAL PARK SERVICE

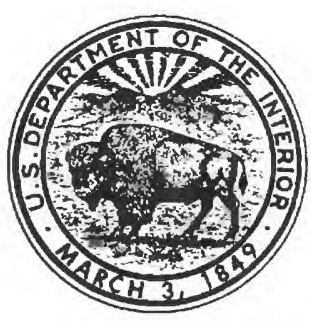

Salt Lake City, Utah 
U.S. DEPARTMENT OF THE INIERIOR

MANUEU LUJAN, JR., Secretary

U.S. GEOLOGICAL SURVEY

Dallas L. Peck, Director

For additional information write to:

District Chief

U.S. Geological Survey

Room 1016 Administration Building

1745 West 1700 South

Salt Lake City, Utah 84104
Copies of this report can be purchased from:

U.S. Geological Survey

Books and Open-File Reports Section

Federal Center

Box 25425

Denver, Colorado 80225 


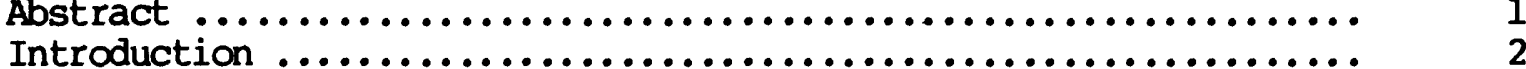

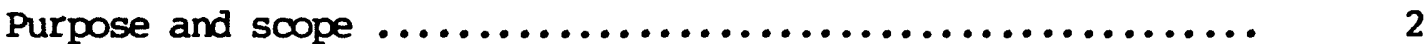

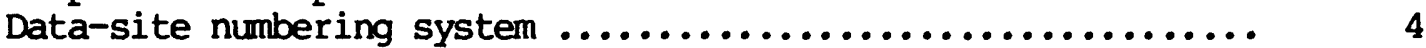

Climate, topography, and vegetation .................... 4

Regional geology ................................. 7

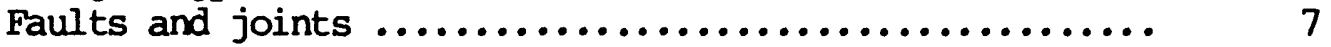

Stratigraphy and lithology ...................... 10

Description of the hydrologic system in the Navajo Sandstone ...... 10

Aquifer gecmetry $\ldots \ldots \ldots \ldots \ldots \ldots \ldots \ldots \ldots \ldots \ldots \ldots \ldots \ldots \ldots \ldots . \ldots \ldots \ldots$

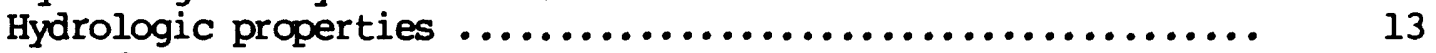

Ground-water movement .............................. 15

Ground-water budget for the Navajo aquifer ............... 16

Sources of recharge to the Navajo aquifer ............. 18

Sources of discharge from the Navajo aquifer ........... 19

Simulations of ground-water flow in the Navajo aquifer .......... 21

Design and construction of the flow model ................ 22

Simulation of recharge and discharge .................... 24

Alternative steady-state simulations ................... 25

Alternative 1--unrestricted flow across the Sevier

Fault ..................................... 25

Alternative 2--no flow across the Sevier Fault ......... 28

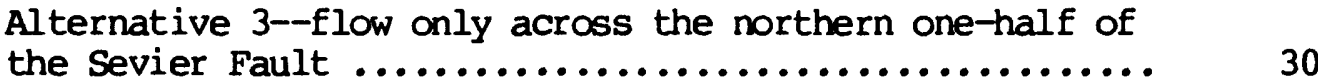

Sensitivity analysis .............................. 35

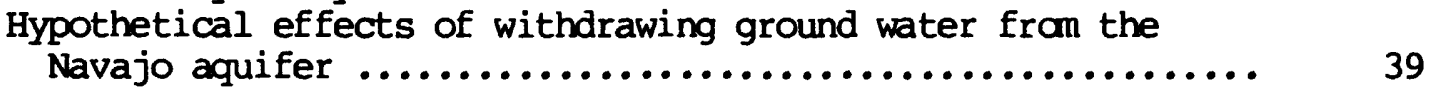

Suggestions for further study $\ldots \ldots \ldots \ldots \ldots \ldots \ldots \ldots \ldots \ldots \ldots \ldots \ldots \ldots \ldots \ldots$

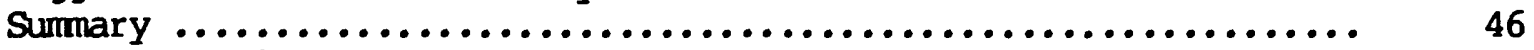

References cited $\ldots \ldots \ldots \ldots \ldots \ldots \ldots \ldots \ldots \ldots \ldots \ldots \ldots \ldots \ldots \ldots \ldots \ldots \ldots . \ldots \ldots$

\section{IIUUSTRATIONS}

[Plates are in pocket]

Plate 1. Map showing generalized geology and regional structure, areas of phreatophyte growth, gaining and losing reaches of streams, and spring and well locations in western Kane, eastern Washington, and southern Iron and Garfield Counties, Utah, and northern Mohave and Coconino Counties, Arizona.

2. Map showing model grid identifying recharge, river, drain, and well cells in model layer 1, western Kane, eastern Washington, and southern Iron and Garfield Counties, Utah, and northern Mohave and Coconino Counties, Arizona.

3. Map showing model grid identifying recharge, river, drain, well, and fault cells in model layer 2, western Kane, eastern Washington, and southern Iron and Garfield Counties, Utah, and northern Mohave and Coconino Counties, Arizona 
Figure 1. Map showing location of study area, outcrop of

2. Navajo Sandstone, and major coal seams $\ldots \ldots \ldots \ldots \ldots$

Page

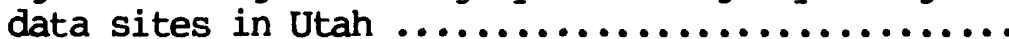

3. Map showing mean winter precipitation for 1931-60 (cumulative for october through April) ...........

4. Diagram showing schematic section across the study area indicating assumed thickness, attitude, and stratigraphic relation of younger and older formations with the Navajo Sandstone, in Kane and Washington counties, Utah ...........

5. Map showing fracture pattern within Zion National

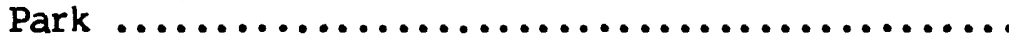

6. Diagram showing schematic section across the Kanab block indicating assumed thickness, attitude, and stratigraphic relation of younger and older formations with the two members of the Navajo Sandstone, in Kane county, Utah ................

7. Graphs showing monthly precipitation at Kanab, Utah, and spring discharge at Pipe Spring National Monument, Arizona ........................

8. Diagrammatic section showing model layers representing the Navajo aquifer within the study area ............................

Figures 9-18. Maps showing:

9. Steady-state simulated water-level contours in layer 1 for Alternative 1 (unrestricted flow across the Sevier Fault) ..............

10. Steady-state simulated water-level contours in layer 1 for Alternative 2 (no flow across the Sevier Fault) ................

11. Steady-state simulated water-level contours in layer 1 for Alternative 3 (partial flow across the Sevier Fault) .................

12. Steady-state simulated water-level contours in layer 2 for Alternative 1 (unrestricted flow across the sevier Fault) ..............

13. Steady-state simulated water-level contours in layer 2 for Alternative 2 (no flow across the Sevier Fault) .....................

14. Steady-state simulated water-level contours in layer 2 for Alternative 3 (partial flow

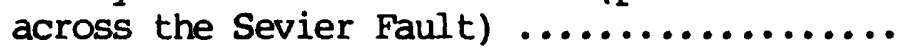

15. Water-level declines in layer 1 after 30 years of simulated pumping of 4,000 acre-feet per year near Bald Knoll using smallest estimated storage values (Alternative 3 ) ...

16. Water-level declines in layer 2 after 30 years of simulated pumping of 4,000 acrefeet per year near Bald Knoll using smallest estimated storage values (Alternative 3) ... 


\section{TIUSTRATIONS}

Page

Figure

17. Water-level declines in layer 1 after 30 years of simulated pumping of 4,000 acrefeet per year near Bald Knoll using largest estimated storage values (Alternative 3) ...

18. Water-level declines in layer 2 after 30 years of simulated pumping of 4,000 acrefeet per year near Bald Knoll using largest estimated storage values (Alternative 3) ...

TABLES

Table 1. Components of the steady-state ground-water budget

2. Measured and simulated water levels in selected

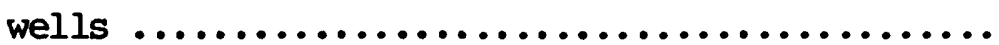

3. Ground-water budgets and flow across the Sevier and Paunsaugunt Faults for the three alternative

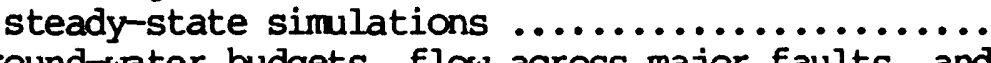

4. Ground-water budgets, flow across major faults, and water-level declines at Bald Knoll for the three alternative simulations using the smallest and largest storage values for each simulation of hypothetical withdrawals near Bald Knoll......... 


\section{CONVERSION FACTIORS AND VERTICAL DATUM}

\section{Multiply}

acre

acre-foot (acre-ft)

acre-foot per year (acre-ft/yr)

cubic foot per second ( $\mathrm{ft}^{3} / \mathrm{s}$ )

foot ( $\mathrm{ft}$ )

foot per day (ft/d)

foot per day per foot $[(\mathrm{ft} / \mathrm{d}) / \mathrm{ft}]$

foot squared per day ( $\mathrm{ft}^{2} / \mathrm{d}$ )

gallon per minute per foot (gal/min/ft)

inch (in.)

mile ( $\mathrm{mi}$ )

square mile $\left(\mathrm{mi}^{2}\right)$

ton (short)
By

0.4047

0.001233

0.001233

0.02832

0.3048

0.3048

1

0.0929

0.207

\subsection{4 \\ 1.609 \\ 2.59 \\ 0.9072}

To obtain

hectare

cubic hectometer

cubic hectometer per year

cubic meter per second

meter

meter per day

meter per day per meter

meter squared per day

liter per second per meter

centimeter

kilameter

square kilometer

metric ton

Sea level: In this report "sea level" refers to the National Geodetic Vertical Datum of 1929-a geodetic datum derived from a general adjustment of the first order level nets of the United States and Canada, formerly called Sea Level Datum of 1929. 


\section{SIMULATION OF GROUND-WATER FLOW AND WATER-LEVEL DECLINES THAT}

COULD BE CAUSED BY PROPOSED WITHDRAWALS, NAVAJO SANDSTONE,

SOUTHWESTERN UTAH AND NORTHWESTERN ARIZONA

By Victor M. Heilweil and Geoffrey W. Freethey

ABSTRACT

It has been proposed that water from the Navajo Sandstone be used in developing coal resources in western Kane County, Utah. The Navajo aquifer in western Kane, eastern Washington, and the southernmost parts of Iron and Garfield Counties, Utah, and in northern Mohave and Coconino Counties, Arizona, is the source of stream base flow and spring discharge in Zion National Park and Pipe Spring National Monument. The Navajo aquifer also supplies water for municipal, damestic, stock, and agricultural use in this semiarid region.

Approximately 550,000 acre-feet per year of precipitation falls on the Navajo Sandstone where it crops out between the Paria River and the Hurricane Fault. According to estimates of discharge from the Navajo aquifer, from 50,280 to 68,180 acre-feet of water recharges the Navajo aquifer annually between the Paria River and the Hurricane Fault.

In the areas of exposed outcrop, ground water moves from higher altitude recharge areas to deeply incised canyons where water is discharged to springs and streams. Estimates of total discharge to the North and East Forks of the Virgin River and to Kanab Creek range from 39,800 to 57,700 acre-feet per year. The estimated spring discharge for the study area is 8,140 acre-feet per year. The direction and movement of ground water farther to the north, where the Navajo Sandstone is buried beneath younger formations, is poorly defined because of the lack of wells in the area.

The flow of ground water also is complicated by two large vertically offsetting faults--the Sevier Fault and the Paunsaugunt Fault. In places, these faults have offsets of nearly 2,000 feet, and the hydrologic properties and influence of these faults on ground-water flow have not been determined.

In lieu of further data aoquisition, computer simulations were used to test various alternative concepts of the hydrologic system and its properties, particularly the possibility of east-to-west flow across the Sevier Fault. The results of three alternative steady-state models showed that flow probably does not occur across the southern part of the Sevier Fault where the aquifer is completely offset, but may occur farther north where the offset decreases. Flow across the Sevier Fault for the alternative simulations ranged from 0 to 10,000 acre-feet per year.

Proposed withdrawals of about 4,000 acre-feet per year for 30 years from a well near Bald Knoll were simulated for the three alternative models. The range of storage values used was from 5 to 10 percent for specific yield and from 9.0 $\times 10^{-4}$ to $2.4 \times 10^{-3}$ for storage coefficient. These simulations produced waterlevel declines from 119 to 188 feet at the Bald Knoll pumping site. No substantial water-level declines occurred in the vicinity of Pipe Spring National Monument or Zion National Park in any of the simulations. 


\section{INIRODUCTION}

Southwestern Utah and northwestern Arizona are semiarid but include several areas of scenic beauty that owe their existence, in part, to hydrologic processes. Within a 35-mi radius of the town of Glendale, Utah, four areas have been designated by Federal agencies as parks or monuments (fig. 1). Two of these areas, Zion National Park and Pipe Spring National Monument, are located where ground water from the Navajo Sandstone discharges to springs. The springs are a major tourist attraction of these parks. The Navajo Sandstone, the principal regional aquifer, supplies water for domestic, stock, agricultural, and municipal use by means of springs, wells, and base flow to local streams.

Coal is one of the natural resources of the area. Coal reserves are estimated to be in excess of 4 billion short tons (Doelling and Graham, 1972, p. vii). The most recent proposal for mining near Alton involves slurrying the coal, which would require ground-water withdrawals of approximately 4,000 acreft/yr from the Navajo Sandstone at Bald Knoll (Todd, 1987, p. V).

Because of the complexity of the ground-water system caused by a disruption of the lateral continuity of the aquifer by offset of several large southtrending faults, and because of the lack of wells in the area, direction and rate of movement of water in the Navajo Sandstone have not been conclusively defined. Thus, effects of withdrawals on ground-water levels within the study area cannot be determined precisely.

\section{Purpose and Scope}

At the request of the National Park Service, the U.S. Geological Survey conducted a study to determine the potential range of effects that proposed ground-water withdrawals associated with coal mining would have on water levels in and rates of discharge from the Navajo Sandstone. The purpose of this report is to document the effects of these proposed ground-water withdrawals using three alternative concepts of the hydrologic system. The report also describes the computer simulations used to demonstrate the three concepts of how ground water moves through the Navajo Sandstone from recharge to discharge areas.

In general, the scope of this study was limited to compiling and interpreting data from previous investigations for use in the computer simulations. One exception was the completion of a seepage study on the East Fork Virgin River to more accurately quantify the ground-water budget in this area. The study did not include a detailed hydrologic analysis of the overlying or underlying geologic formations because these formations are considered much less permeable than the Navajo Sandstone, and thus are not a part of the principal ground-water system.

The study area includes approximately $2,600 \mathrm{mi}^{2}$ where the Navajo Sandstone crops out or is buried in western Kane, eastern Washington, and the southernmost parts of Iron and Garfield Counties, Utah, and the northern parts of Mohave and Coconino Counties, Arizona (pl. 1). Because the northern extent of the Navajo Sandstone is unknown, the northern boundary of the study area was chosen distant enough so that it would not be affected by the proposed withdrawals at Bald Knoll. The western and southern boundaries of the study area are at or near the erosional extent of the Navajo Sandstone. The eastern boundary is east of the Paria River, which flows across the Navajo Sandstone and younger formations. 


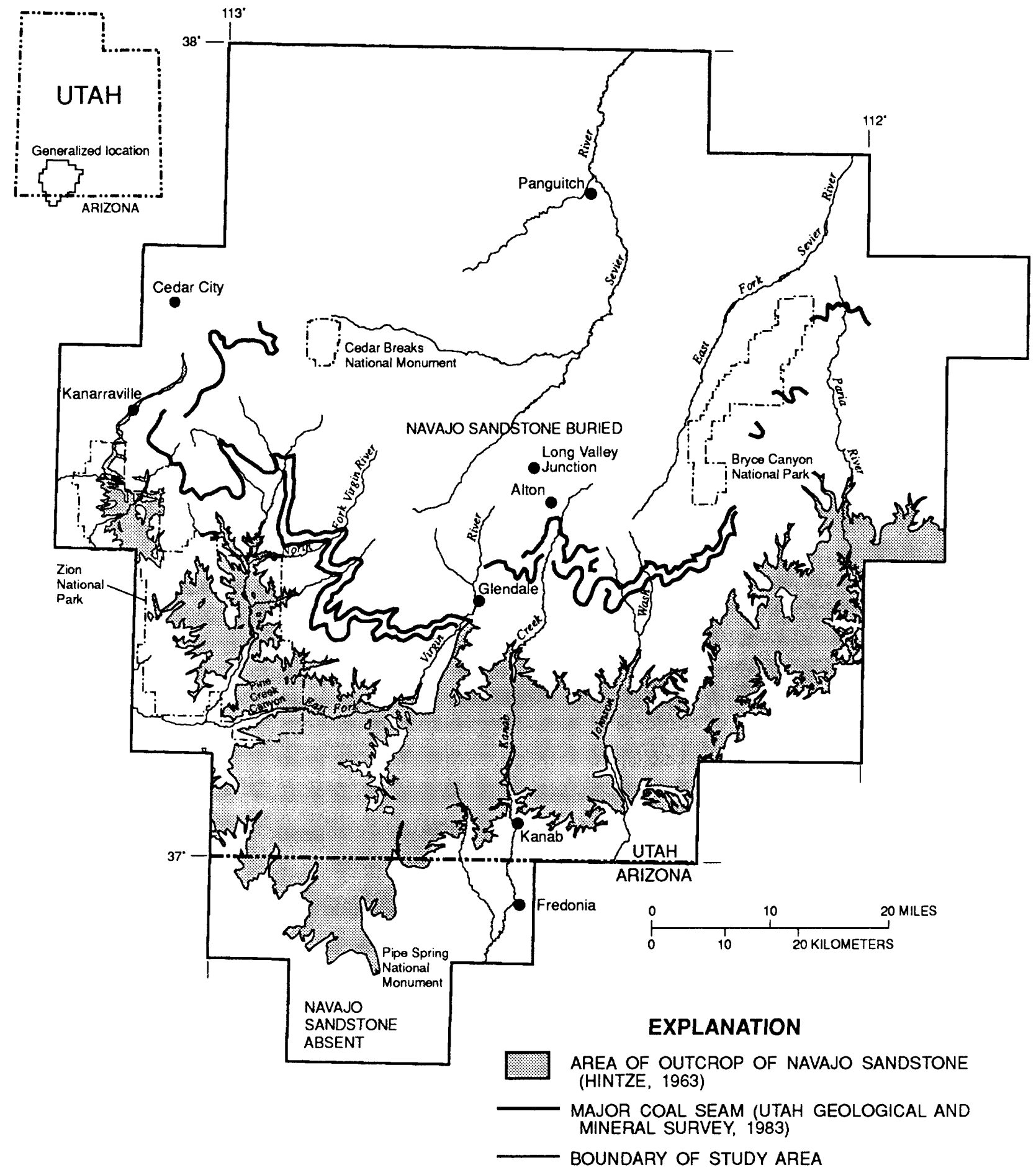

Figure 1.--Location of study area, outcrop of Navajo Sandstone, and major coal seams. 
Previous hydrologic and geologic investigations for the study area are described by Freethey (1988, p. 3-4). Two additional reports that were also important to this study are Uygur's laboratory study (1980) of hydrologic properties of the Navajo Sandstone and Gregory's description (1950) of the geology and geography in the Zion National Park region of Utah and Arizona.

\section{Data-Site Numbering System}

The system for identifying and locating geohydrologic-data sites in Utah is based on the cadastral land-survey system of the U.S. Government. An assigned number, in addition to designating a well, spring, or related site, describes its position in the land net. The State is divided into four quadrants by the Salt Lake Base Line and the Salt Lake Meridian (fig. 2). These quadrants are designated by A, B, C, and D, indicating, respectively, the nor theast, northwest, southwest, and southeast quadrants. Numbers designating the township and range follow the quadrant letter, and all three are enclosed in parentheses. The number after the parentheses indicates the section and is followed by three letters indicating the quarter section, the quarter-quarter section, and the quarter-quarter-quarter section-generally 10 acres. The letters $a, b, c$, and d indicate, respectively, the northeast, northwest, southwest, and southeast quarters of each subdivision. The number after the letters is the serial number of the well or spring within the 10-acre tract. The letter "S" preceding the serial number denotes a spring. For the half ranges (such as R. $4 \frac{1}{2}$ W.) within the study area, the letter " $R$ " precedes the parentheses. If a site cannot be located within a 10-acre tract, one or two location letters are used and the serial number is omitted. Thus $(C-40-5) 24$ bad- 1 designates the first well visited in the southeast quarter of the northeast quarter of the northwest quarter of section 24, T. 40 S., R. 5 W. (fig. 2).

\section{Climate, Topography, and Vegetation}

The study area includes the upper drainage basins of the North Fork and East Fork Virgin River, Kanab Creek, Johnson Wash, the Sevier River, and the Paria River (fig. 1). The area generally is semiarid; mean annual precipitation ranges from 10 to 40 in. (U.S. Weather Bureau, 1963a, 1963c). There is a general trend of increasing precipitation toward the central northwest part of the study area (fig. 3) because of an overall increase in altitude from 5,000 to $11,000 \mathrm{ft}$ above sea level. As Blanchard noted in his study (1986, p. 17) of the area to the east along the Kaiparowits Plateau, a larger percentage of normal annual precipitation falls from October through April at higher altitudes than falls during that period at lower altitudes.

The topography of the exposed Navajo Sandstone outcrop includes cliffs and deeply eroded, narrow canyons on the west side of the study area in $\mathrm{Zion}$ National Park and sandy, rolling terraces and wide canyons in the Kanab and Johnson drainages to the east. Phreatophyte growth is related to this variation in topography; phreatophytes are more cormon in the eastern and central parts of the study area than in the western part. 
Sections within a township

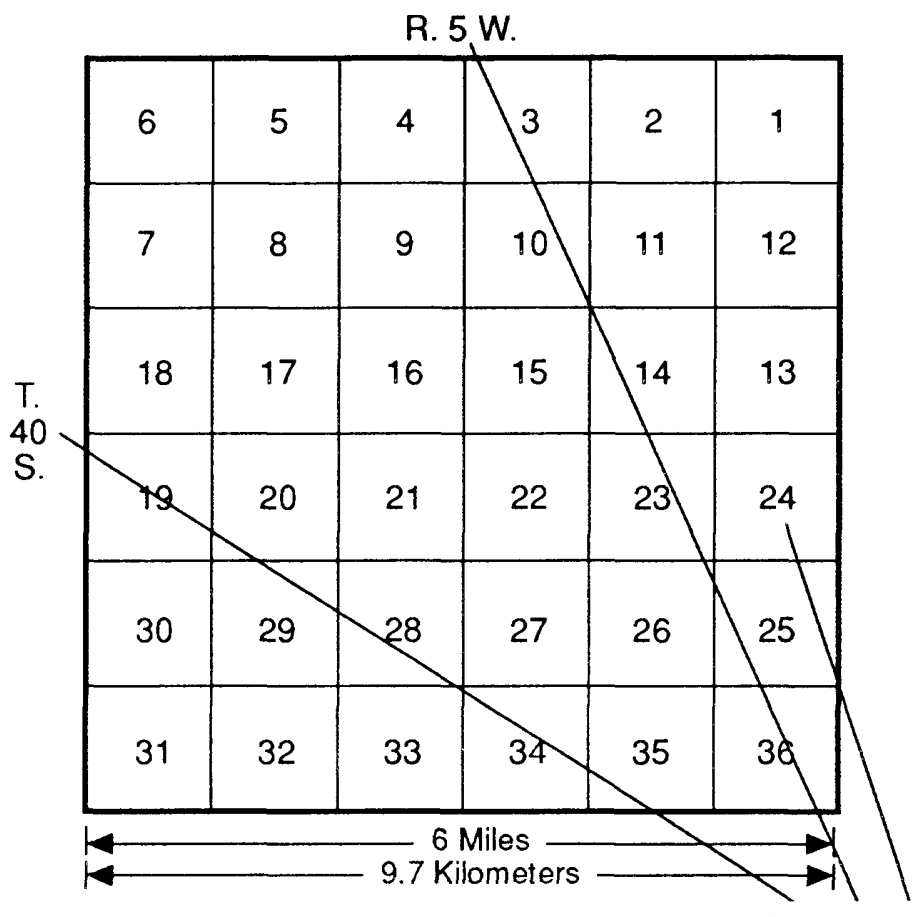

Tracts within a section

Section 24
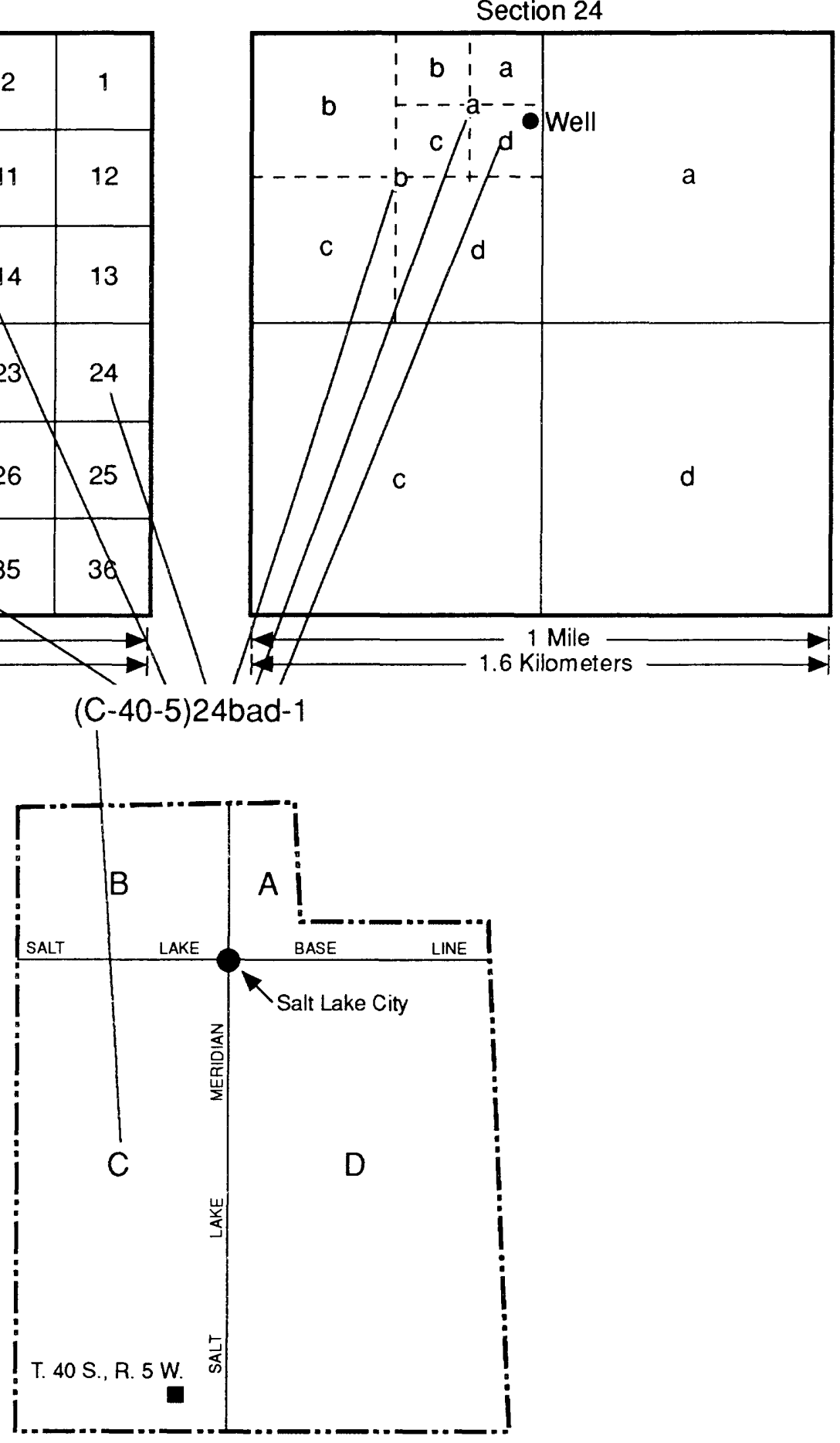

Figure 2.--Numbering system for geohydrologic-data sites in Utah. 


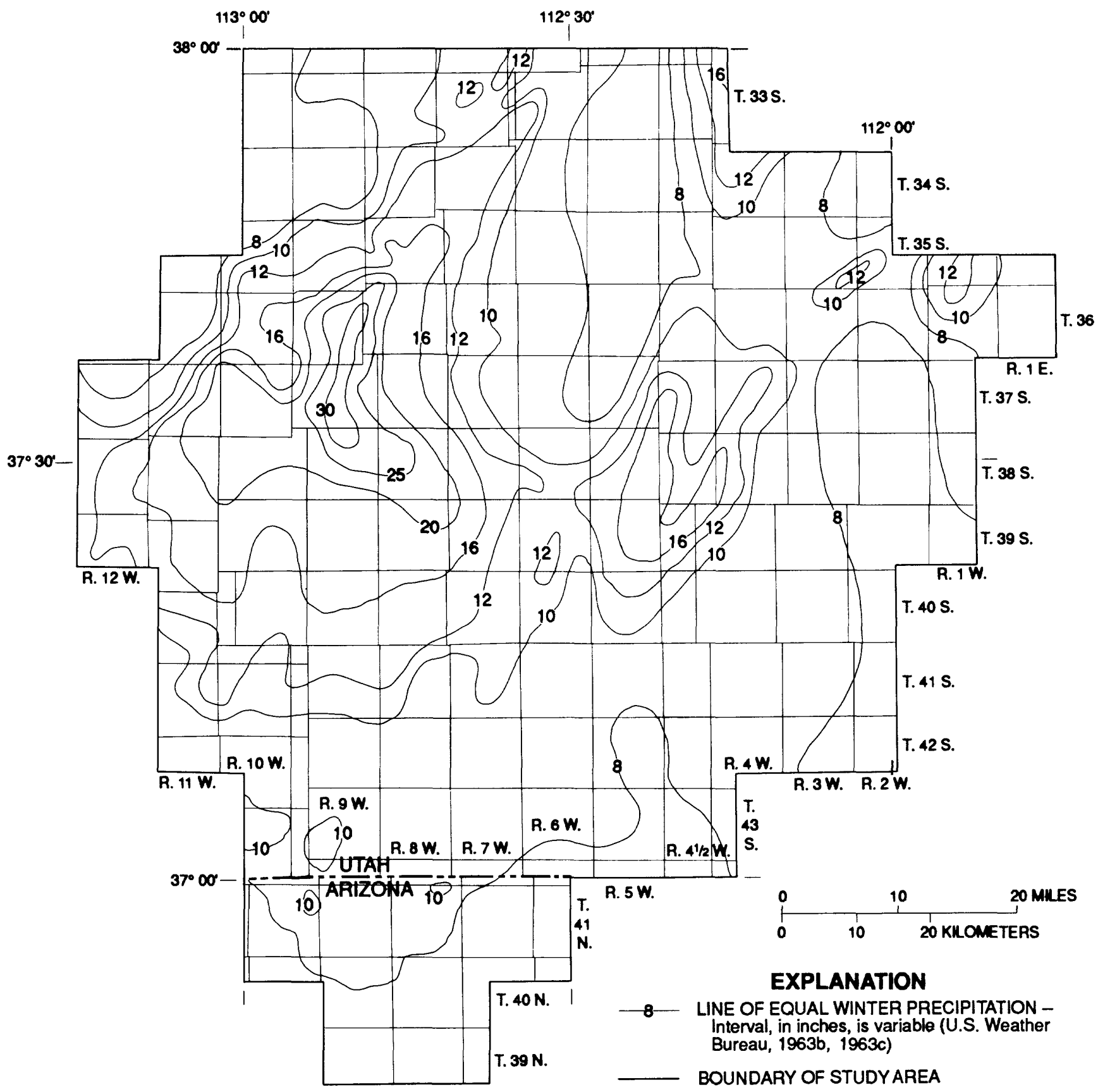

Figure 3.--Mean winter precipitation for 1931-1960 (cumulative for October through April). 


\section{Regional Geology}

The geologic formations present in the study area range in age from Permian to Holocene and are structurally disturbed by three large displacement faults, numerous small displacement faults, and by a regional dip to the north (fig. 4). The Navajo Sandstone of Early Jurassic age is one of many sedimentary layers deposited in the study area during the Mesozoic Era. Subsequent regional uplift and compression of the Colorado Plateau Physiographic Province (Fenneman, 1931) and more recent extensional tectonic forces are responsible for the present geologic structure of the region (Hamilton, 1984, p. 89-101). All of the formations generally dip from 1 to 5 degrees to the north-northeast, although dip angles are much steeper near major faults. A syncline (fig. 4) with axis plunging gently to the north-northeast lies between the Sevier and Paunsaugunt Faults (Bingham Engineering, 1987, p. III-6). This syncline is expressed at the surface by the "U" shape of the Navajo Sandstone outcrop (pl.1) and causes localized variations in the dip orientation.

\section{Faults and Joints}

In the study area, the Navajo Sandstone and underlying and overlying formations are separated laterally into three structurally offset blocks by three major faults - the Hurricane, the Sevier, and the Paunsaugunt (pl. 1). The blocks will be referred to throughout this report (from west to east) as the Zion block, the Kanab block, and the Paria block (pl. 1 and fig. 4). The three bounding faults are all south-southwest trending high-angle normal faults with displacement down to the west.

The Hurricane Fault has an estimated maximum vertical displacement of 8,000 ft near Kanarraville and more than 5,000 ft farther south at the Virgin River (Gregory, 1950, p. 144). The Sevier Fault, traceable for more than $200 \mathrm{mi}$, has a maximum vertical displacement of more than 2,000 ft near the Utah-Arizona border. Its offset decreases farther north to less than 1,000 ft north of Long Valley Junction (Gregory, 1950, p. 143-145). In contrast, displacement along the Paunsaugunt Fault increases from less than $200 \mathrm{ft}$ in the south to more than 1,500 ft in the north part of the study area (Bingham Engineering, 1987, p. III6). Numerous other faults in the study area have smaller offsets than these three and are less likely to affect the lateral continuity of the Navajo Sandstone (pl. 1 and fig. 4).

Jointing, like faulting, also is a common characteristic of the Navajo Sandstone. According to geologic maps and satellite images of the area, jointing is particularly pronounced on the west side of the study area within the zion block (Hamilton, 1984, p. 22). The predominant orientation of the joint set is north-northwest in Zion National Park (fig. 5). There is a secondary set of more closely spaced joints trending east-northeast. A survey of joint sets by Gregory (1932) in Pine Creek Canyon of Zion National Park indicates that the primary joints are more continuous and generally have wider apertures than the secondary joints. Most of the primary joints are vertically continuous through the Navajo Sandstone and vary from being tightly cemented by minerals deposited by percolating ground water to wide uncemented cracks filled only with loose sand (Gregory, 1950, p. 152-153). 


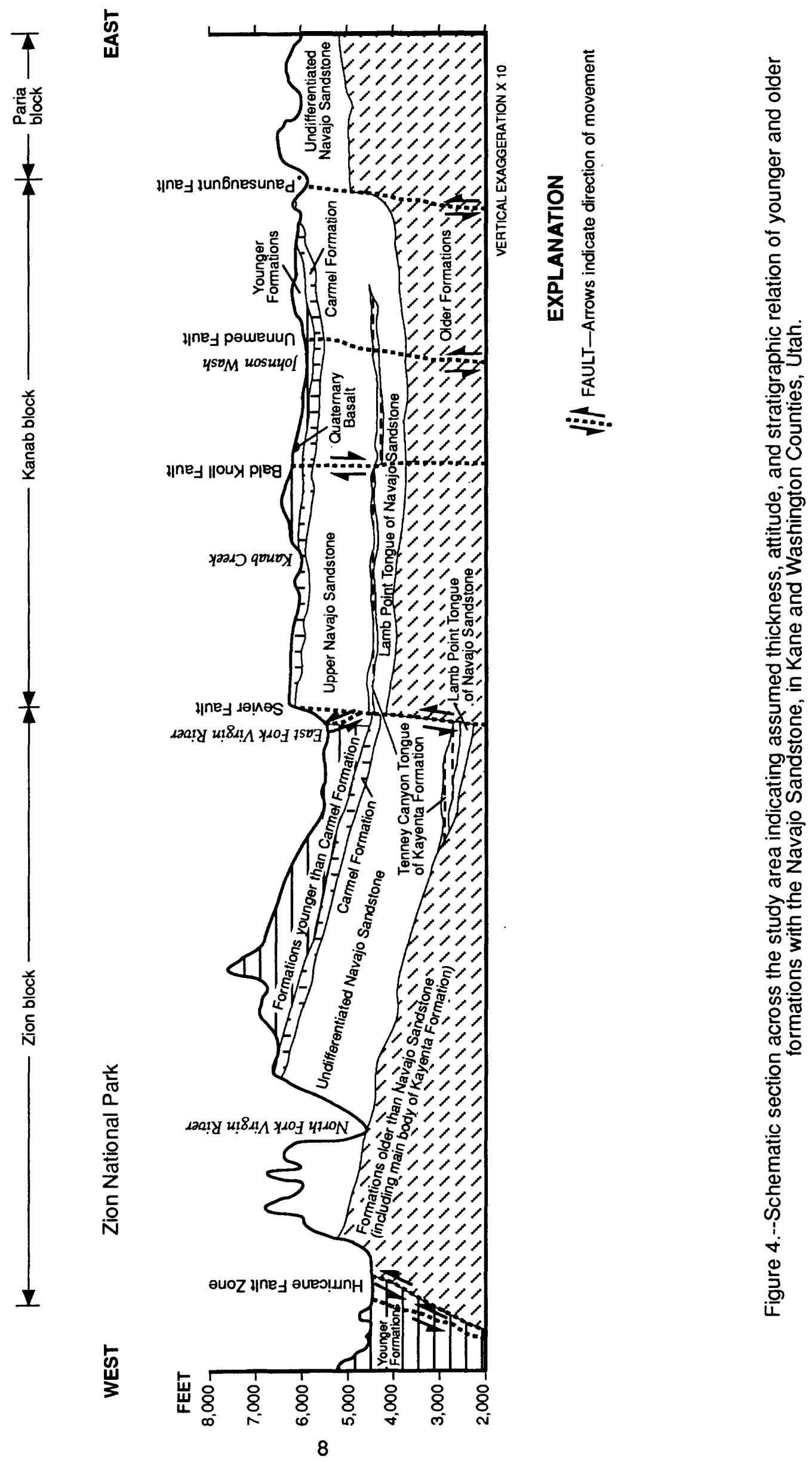




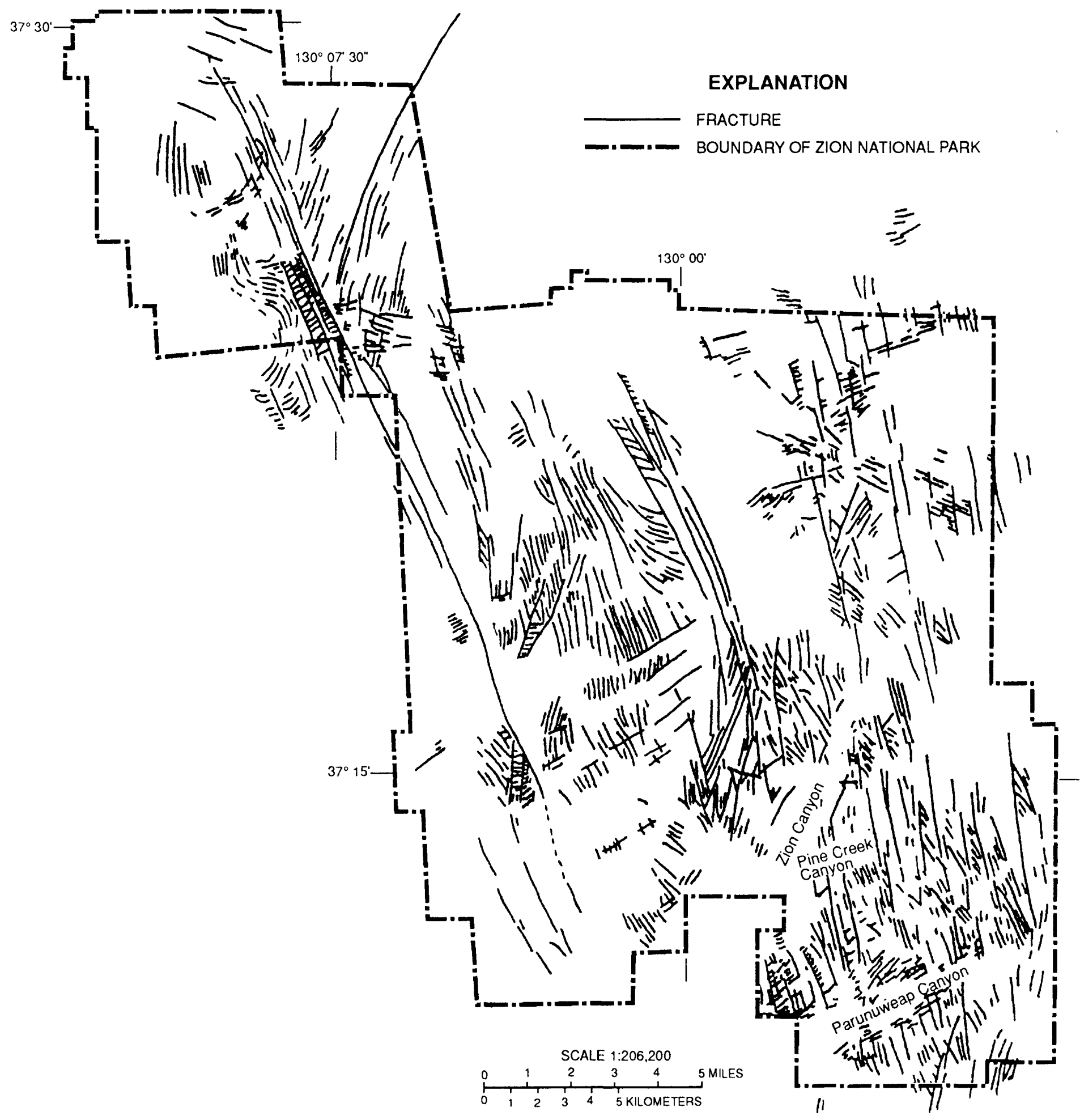

Figure 5.--Fracture pattern within Zion National Park (Modified from Hamilton, 1984, figure 35). 


\section{Stratigraphy and Lithology}

The Navajo Sandstone is a homogeneous, fine-grained, calcite-cemented quartz sandstone. Its thickness varies from about 1,400 ft at the Paria River to about 1,800 ft near Zion National Park (Gregory, 1950, p. 83). Beneath the Navajo Sandstone are less permeable siltstone and very fine-grained sandstone of the Kayenta Formation (Early Jurassic). Above the Navajo Sandstone are less permeable clay and siltstone of the Carmel Formation (Middle Jurassic) (figs. 4 and 6). Locally, Quaternary basalt flows (pl. 1) and unconsolidated alluvial deposits (not shown on pl. 1) overlie the otherwise-exposed Navajo Sandstone (Freethey, 1988, p. II; Bingham Engineering, 1987, p. III-3 to III-5; Hintze, 1963).

The Navajo Sandstone in the Zion block is largely undifferentiated. In the eastern part of the Zion block, a member of the Kayenta Formation, the Tenney Canyon Tongue, isolates a small thickness of the Navajo Sandstone, the Lamb Point Tongue, fram the main body of the Navajo Sandstone (fig. 4). Farther west in the $\mathrm{Zion}$ block, the Lamb Point Tongue thins and the Tenney Canyon Tongue joins with the main body of the Kayenta Formation (fig. 4).

Within the Kanab block, the Navajo Sandstone is divided by the Tenney Canyon Tongue of the Kayenta Formation into two units--the Lamb Point Tongue and an upper unnamed member (herein referred to as the upper Navajo Sandstone)(fig. 6). Similar to the main body of the Kayenta Formation, the Tenney Canyon Tongue consists of siltstone and very fine-grained sandstone and tends to impede vertical movement of ground water. It is more than $100 \mathrm{ft}$ thick just east of the Sevier Fault, but pinches out in the area west of the Paunsaugunt Fault and east of Johnson Wash. Because the Tenney Canyon Tongue pinches out, there is a small section of undifferentiated Navajo Sandstone in the southeast corner of the Kanab block (fig. 4). The Lamb Point Tongue thins from about $600 \mathrm{ft}$ in the northeast to extinction west of Pipe Spring National Monument. In conjunction with this, the upper Navajo Sandstone increases in thickness to the south and west, thus maintaining an approximate 2,000-ft thickness for the Navajo Sandstone (Freethey, 1988, p. 11; Bingham Engineering, 1987, p. III-2 to III-5).

The Navajo Sandstone in the Paria block is undifferentiated because the Tenney Canyon Tongue pinches out west of the Paunsaugunt Fault (Bingham Engineering, 1987, p. III-2 to III-5; Cordova, 1981, p. 10-11). Because the Paria block is the highest upthrown block, the Navajo Sandstone is more extensively eroded and thinnest within this block (fig. 4).

\section{DESCRIPTION OF THE HYDROLOGIC SYSTEM IN THE NAVAJO SANDSTONE}

\section{Aquifer Geametry}

The fully saturated part of the Navajo Sandstone through which ground water flows will herein be referred to as the Navajo aquifer. The hydrologic properties of the Navajo aquifer and surrounding units are directly related to lithology and structure. The Navajo aquifer is confined at its base by the less permeable Kayenta Formation, and where buried, is confined at its upper formational contact by the overlying Carmel Formation. The Tenney Canyon Tongue of the Kayenta Formation impedes vertical ground-water movement within 
$\frac{1}{2}$

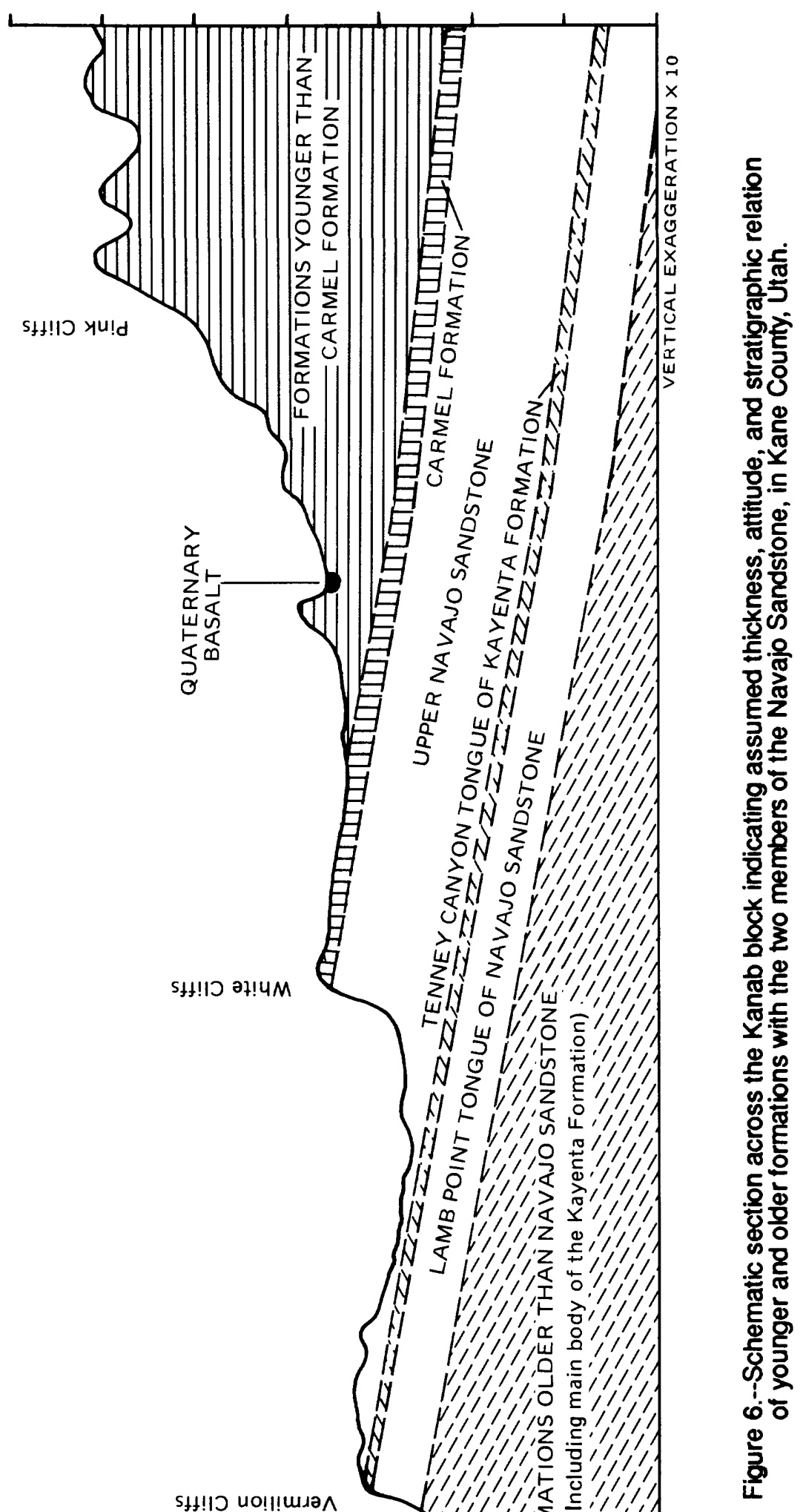

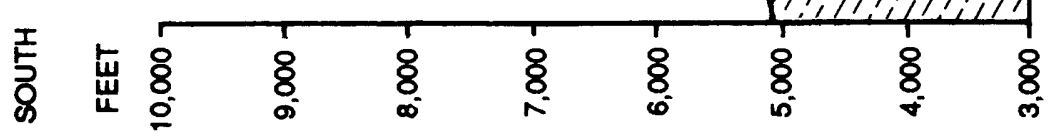


the Navajo aquifer in the central part of the study area and divides the Navajo aquifer into two aquifers, which will be referred to as the Lamb Point aquifer and the upper Navajo aquifer. The less permeable layers mentioned above will be referred to as the the Kayenta confining unit, the Carmel confining unit, and the Tenney Canyon confining unit. The division of the Navajo aquifer by the Tenney Canyon confining unit is only hydrologically important in the Kanab block. Farther east, the Tenney Canyon confining unit pinches out, and farther west, the Lamb Point aquifer thins so as to be hydrologically unimportant.

In the Zion block, the Navajo aquifer is unconfined where it crops out. To the north and east, where the Navajo aquifer dips beneath the Carmel confining unit, it is assumed to become confined. The location at which this transition occurs is unknown because of lack of data. Also, it is assumed that the potentiometric surface flattens to the north, but no deep well water-level measurements are available in this area to substantiate this assumption.

The hydrologic boundaries of the Navajo aquifer in the Zion block are mainly defined by geologic features. The western and southern hydrologic boundaries of the $\mathrm{Zi}$ ion block are the erosional limits of the Navajo Sandstone. The eastern boundary is the Sevier Fault. Ground-water movement across the fault has not been conclusively determined but is thought to occur where the fault offset is less than the thickness of the Navajo aquifer. The character of the northern hydrologic boundary is not known, but because of the increasing depth of the aquifer and the apparent absence of any discharge area to the north, it is assumed that ground-water movement is minimal.

In the area defined as the Kanab block, the Lamb Point and upper Navajo aquifers are unconfined where they crop out (fig. 6). Well records show that the Lamb Point aquifer becomes confined to the north where it is overlain by the Tenney Canyon confining unit. The upper Navajo aquifer remains unoonfined for some unknown distance north of the White Cliffs (Freethey, 1988, p. 12).

In Bald Knoll well (C-40-5)2labc-1, the uppermost $310 \mathrm{ft}$ of the upper Navajo Sandstone is unsaturated (Bingham Engineering, 1981, p. 11) so that the Lamb Point and upper Navajo aquifers have a combined saturated thickness of approximately 1,700 ft. It is assumed that at some distance north of Bald Knoll, the upper Navajo aquifer becomes confined by overlying less-permeable layers as it dips below the altitude of the potentiometric surface at Bald knoll. It is assumed, therefore, that the saturated thickness to the north increases to approximately 2,000 ft. The configuration of the potentiometric surface north of Bald Knoll is unknown. Because water levels in the wells at Bald Knoll and in wells 10 miles to the south-southeast (Freethey, 1988, table 4 , pl. 2) are about the same, resulting in a nearly flat gradient, it is assumed that the hydraulic gradient north of Bald Knoll is also virtually flat.

The hydrologic boundaries of the Navajo aquifer in the Kanab block are mostly structural and stratigraphic in origin. The sevier Fault is the western boundary of the Kanab block. Because the displacement of the Sevier Fault in the southern part of the study area is large enough to completely offset the Navajo aquifer, it is questionable whether east-west ground-water flow occurs across the fault in this area. No hydrologic data are available to determine if a hydraulic connection exists. 
The Paunsaugunt Fault is the eastern boundary of the Kanab block. Unlike the Sevier Fault, the displacement across the Paunsaugunt Fault is not large enough to completely offset the Navajo aquifer. The only hydrologic data available for the area near the Paunsaugunt Fault are from two wells about $3 \frac{1}{2}$ miles apart in the southern part of the Navajo Sandstone outcrop: (c-42-4) 19adb-1, west of the fault, and (c-42-4)3bac-1, east of the fault (pl. 1). The drillers' logs for these two wells indicate that the throw of the fault in this area is probably less than $500 \mathrm{ft}$ (Freethey, 1988, p. 28). The well east of the fault completely penetrates the Navajo Sandstone, and at this well, the Navajo Sandstone was unsaturated. Thus, it is assumed that no ground water flows across the fault in this area. The undifferentiated Navajo Sandstone farther north in the Paria block is at least partially saturated because of the northward dip of the Navajo Sandstone. Thus, it is assumed that a partial hydrologic connection exists across the Paunsaugunt Fault, at least where the Navajo Sandstone is buried to the north.

In the Paria block, the Navajo aquifer is undivided because the Tenney Canyon confining unit is absent. There have been no wells drilled in the Paria block where the Navajo aquifer is buried to the north. Similar to the Navajo aquifer of the Zion block, the Paria block is an unconfined aquifer in the outcrop area and is assumed to be confined at some distance north of the outcrop.

The northern and southern hydrologic boundaries for the Paria block are similar to the northern and southern hydrologic boundaries of the Zion and Kanab blocks. The western boundary of the Paria block is the Paunsaugunt Fault. A hydraulic connection probably exists across the fault along the northern part of this western boundary (as noted above). Well data indicate, however, that along the southern part of this western boundary, a hydraulic connection might not exist. The south and the southeastern hydrologic boundaries of the Paria block are the erosional limits of the Navajo Sandstone. Farther to the north on the eastern boundary, the Paria River forms a source of recharge for the Navajo aquifer if the altitude of the river is higher than potentiometric surface of the aquifer; and it is a discharge line if the altitude of the river is lower than the potentiometric surface of the aquifer.

\section{Hydrologic Properties}

Hydrologic properties are necessary for describing the rate of ground-water flow, the quantity of water stored in an aquifer, and the decline of waterlevels caused by withdrawals. Hydraulic conductivity (expressed in $\mathrm{ft} / \mathrm{d}$ ) of an aquifer in the vertical and horizontal directions is defined as the volume of water at the existing kinematic viscosity that will move in unit time under a unit hydraulic gradient through a unit area measured at right angles to the direction of flow (Lohman and others, 1972, p. 4). The vertical hydraulic conductivity of a confining unit is the rate of leakage across a horizontal confining unit that separates two aquifers.

Specific yield (expressed in percent) is the volume of water released from an unconfined aquifer because of a unit decline in the water level. Similarly, the storage coefficient is the volume of water released from a confined aquifer because of a unit decline in the water level (Bedient and Huber, 1988, p. 493). Specific storage (expressed in feet $^{-1}$ ) is the storage oofficient per vertical unit of thickness. Specific capacity (expressed in gal/min/ft) of a well is 
defined as the withdrawal rate divided by the water-level decline in the well. It is a measure of the productivity of the well and can also be used as a qualitative measure of the ability of the aquifer to transmit water.

Laboratory measurements of three samples from the Navajo aquifer in the Zion block yielded horizontal hydraulic-conductivity values from 1.77 to 3.32 $\mathrm{ft} / \mathrm{d}$ and vertical hydraulic-conductivity values from 0.32 to $5.00 \mathrm{ft} / \mathrm{d}$ (Uygur, 1980, table 2; Freethey, 1988, table 3). Laboratory measurements of 11 samples from the upper Navajo aquifer of the Kanab block ranged from 0.12 to $6.1 \mathrm{ft} / \mathrm{d}$ for horizontal hydraulic conductivity and fram 0.01 to $5.0 \mathrm{ft} / \mathrm{d}$ for vertical hydraulic conductivity (Freethey, 1988, table 3). Three samples from the Lamb point aquifer in the Kanab block had smaller values: from 0.002 to $4.2 \mathrm{ft} / \mathrm{d}$ in the horizontal direction and from 0.005 to $2.2 \mathrm{ft} / \mathrm{d}$ in the vertical direction (Freethey, 1988, p. 17). This difference may be explained by Uygur's laboratory findings $(1980, \mathrm{p} . \mathrm{V})$ that show a general decrease in mean grain size and increase in sorting (uniformity) and cementation with depth in the Navajo aquifer. Two samples from the undifferentiated Navajo aquifer of the Paria block have been analyzed. Horizontal hydraulic conductivity was 0.38 and 0.64 $\mathrm{ft} / \mathrm{d}$, and vertical hydraulic conductivity was 0.22 and $0.41 \mathrm{ft} / \mathrm{d}$ (Freethey, 1988, table 3). These values are at the lower end of the range of values determined for the Kanab block. Also, laboratory measurements for all of the Navajo aquifer samples generally showed horizontal hydraulic conductivity to be approximately 2.5 times larger than vertical hydraulic conductivity (Freethey, 1988, p. 16).

Vertical hydraulic conductivity of the Tenney Canyon confining unit was determined using the ratio method of Neuman and Witherspoon (1972) from the results of an aquifer test at Oak Canyon well (C-42-5)2ldda. The estimated range was from 0.0052 to $0.42 \mathrm{ft} / \mathrm{d}$ and was based on a range of specific-storage values from $5.0 \times 10^{-5} / \mathrm{ft}$ to $5.0 \times 10^{-6} / \mathrm{ft}$ (Bingham Engineering, 1987, table V1).

Hydraulic-conductivity values would be larger in areas where the aquifer is highly fractured because ground-water flow in these areas is likely dominated by flow through open joints and fractures. The largest values of hydraulic conductivity for the study area were measured near the Bald knoll Fault in the Kanab block (pl. 1). An analysis of aquifer tests for two wells, $(C-40-5) 21 a b b-1$ and $(C-40-5) 21 a b c-1$ (screened in the upper Navajo and Lamb Point aquifers), indicated average hydraulic-conductivity values of $7.55 \mathrm{ft} / \mathrm{d}$ horizontally and $0.52 \mathrm{ft} / \mathrm{d}$ vertically (Freethey, 1988, table 3 ).

Fracturing within the Navajo aquifer also creates anisotropic-flow conditions (Hood and Danielson, 1979, p. 30). Horizontal hydraulic conductivity parallel to the predominant north-northwest joint orientation is probably larger than in other directions. However, neither aquifer-test nor laboratory-analysis data exist to confirm this possibility.

Specific-capacity values for wells also indicate fracturing as a major factor affecting ground-water flow rates. Freethey (1988, p. 16) determined that wells within 2,000 ft of known faults had ranges of specific-capacity values an order of magnitude greater than those of wells farther than 2,000 ft from faults. 
Specific-yield and storage-coefficient values have only been determined at a few locations for the Navajo aquifer. At Bald Knoll, where the upper Navajo aquifer is unconfined, a specific-yield value of 7 percent was obtained from aquifer tests at pumping well (C-40-5)2labb-l (Bingham Engineering, 1981, p. 1). Hood and Danielson (1979, p. 34) determined that specific-yield values for the Navajo aquifer generally range from 5 to 10 percent. An analysis of aquifer tests, within the study area and in Wayne county just to the northeast of the study area, indicated values for the storage coefficient from $9.0 \times 10^{-4}$ to 2.4 x $10^{-3}$ (Freethey, 1988, p. 17; Hood and Danielson, 1979, p. 32).

\section{Ground-Water Movement}

Ground-water movement in the Navajo aquifer, as indicated by water levels in wells and by the altitude of springs, is from the highest altitudes on the Navajo Sandstone outcrop, usually between major drainages, toward the lowest altitudes at the bottom of the canyons cut into the formation. In the Zion block, ground water moves from the upland area to the canyons formed by the North and East Forks Virgin River and discharges to springs and streams. In the Kanab block, ground water moves from the upland outcrop of Navajo Sandstone to the canyon systems carved by Johnson Wash, Kanab Creek, Cottonwood Creek, and the numerous tributaries to these drainages (Freethey, 1988, pl. 2). In the Paria block, ground water moves to the Paria River canyon from the upland outcrop area, but also may move to the nor thwest into the Kanab block.

Few water-level data were collected north of the White Cliffs where the Navajo aquifer is buried under younger sedimentary rocks (pl. 1). The direction and rate of ground-water movement north of the White Cliffs is unknown, but because recharge to the Navajo aquifer where it is deeply buried is probably small and because no discharge areas are evident, it is probable that waterlevel gradients are slight and ground-water movement in this region is slow. Water levels in four wells that penetrate the upper Navajo aquifer where it is deeply buried along the Bald Knoll Fault of the Kanab block-- (C-40-5)16cdc-l $(5,394 \mathrm{ft}),(\mathrm{C}-40-5) 2 \mathrm{labb}-1(5,397 \mathrm{ft}),(\mathrm{C}-40-5) 2 \mathrm{labc}-1(5,397 \mathrm{ft})$, and $(C-41-5) 5 a a a-1(5,330 \mathrm{ft})$--are lower than those in nearby wells along the exposed outcrop in Johnson Canyon--(C-41-5)26dac-1 $(5,465 \mathrm{ft}),(\mathrm{C}-42-5) 15 \mathrm{bcc}-1$ $(5,446 \mathrm{ft})$, and $(\mathrm{C}-42-5) 30 \mathrm{ada}-1(5,694 \mathrm{ft})$.

Horizontal ground-water movement across the Sevier and Paunsaugunt Faults also is poorly understood. Within the Navajo aquifer, there are no closely spaced sets of observation wells on both sides of either fault to determine the direction and rate of ground-water movement. Three concepts of movement across these faults are as follows: (1) Movement is substantially decreased where the lateral continuity of the Navajo aquifer is disrupted by fault offset (or cut off where the aquifer is completely disconnected); (2) fracturing and fault gouge create anisotropic conditions so that movement is increased parallel to the fault and decreased perpendicular to the fault; or (3) fracturing in the fault zone causes increased movement parallel to and perpendicular to the fault, even where the aquifer is vertically disconnected by the fault. In this case, vertical movement within the fault zone may be the only avenue of ground-water movement between the offset aquifer segments. Additional on-site investigation would be needed to determine the actual hydrologic effects of the major faults within the study area. 
In areas where the Navajo aquifer is recharged by infiltrating precipitation, the vertical head gradient is downward. This is supported by well data in the Kanab block, which show that water levels in the upper Navajo aquifer are generally from 50 to $180 \mathrm{ft}$ higher than corresponding water levels in the Lamb Point aquifer $(5,457 \mathrm{ft}$ above sea level at (C-42-5)21dda-3 open to the upper Navajo aquifer compared to 5,403 ft at (c-42-5)21dda-1 open to the Lamb Point aquifer; $5,459 \mathrm{ft}$ at $(\mathrm{C}-42-6) 19 \mathrm{bdc}-1$ and -2 open to the upper Navajo aquifer compared to $5,277 \mathrm{ft}$ at $(\mathrm{C}-42-6) 19 \mathrm{bdc}-3$ open to the Lamb Point aquifer). Exceptions to this may oocur locally.

Where stream discharge increases from ground-water leakage, the vertical gradient is upward. Faults may also provide avenues for upward movement such as at Moccasin Springs near Moccasin, Arizona (Todd, 1987, fig. 19). Goode (1966, p. 17) also suggested that the large dissolved-solids and sulfate concentrations of water at a spring in lower Kanab Canyon, (C-42-6)4cbc-Sl, discharging at a fault scarp in the Navajo aquifer, is evidence of upward movement of water from underlying formations.

Little is known about vertical movement north of the Navajo Sandstone outcrop. Previous investigators have suggested that downward vertical movement occurs from the overlying Carmel Formation in the $\mathrm{Zion}$ and Kanab blocks (G. Cordy, U.S. Geological Survey, oral commun., 1988; Freethey, 1988, p. 27). This possibility is based on measurements of larger sulfate concentrations and specific-conductance values for water samples from the Navajo aquifer where it is overlain by the gypsum-rich Carmel Formation, compared to corresponding values for water samples from the Navajo aquifer where it is exposed at the surface. Other possible reasons for larger sulfate and dissolved-solids concentrations are contamination from drilling or upward vertical movement of water fran underlying formations.

On the basis of springs discharging from the limestone layer of the Carmel confining unit, Blanchard (1986, p. 27) stated that the unfractured basal unit of the Carmel Formation is poorly permeable and restricts downward movement of water into the Navajo aquifer. He concluded that downward movement of water through the Carmel Formation most likely occurs only in fractured regions or where the dissolution of salts has increased vertical permeability within the Carmel Formation. Additional observation wells in the northern part of the study area designed to measure vertical hydraulic gradients are needed to determine the vertical hydraulic connection between the Carmel confining unit and the Navajo aquifer.

\section{Ground-Water Budget for the Navajo Aquifer}

The ground-water budget presented in table 1 is an approximation. Some of the budget components, such as aquifer recharge from streams, aquifer discharge to streams, aquifer discharge to springs, and well withdrawals, are measured. other values, such as recharge by precipitation, are estimated. Ranges are given for components that have differing reported values or that vary with time. Additional data collection is needed to more precisely define the ground-water budget for the Navajo aquifer within the study area (see Freethey, 1988, p. 36,38$)$. 
Table 1.--Camponents of the steady-state ground-water budget

[Quantity, in acre-ft/yr; <, less than]

(A) Sources of recharge to the Navajo aquifer

1. Recharge by precipitation on the outcrop

2. Recharge from streams: North Fork Virgin River East Fork Virgin River Kanab Creek
Quantity

$$
\begin{array}{r}
5,500-110,000 \\
500-\quad 11,600 \\
2,300 \\
<400 \\
\hline
\end{array}
$$$$
\text { Total }=8,700-114,300
$$

(B) Sources of discharge from the Navajo aquifer

1. Discharge to streams:

North Fork Virgin River

East Fork Virgin River

Kanab Creek

Paria River

$$
\begin{aligned}
& 14,500-{ }^{1,2} 28,000 \\
& 23,700-\quad 26,000 \\
& 1,600-r 3,700 \\
& \text { unknown }
\end{aligned}
$$

Subtotal

$$
\begin{array}{r}
57,700 \\
4,6.73,000 \\
4,5 \frac{3}{5,100} \\
{ }_{4}^{4} 40
\end{array}
$$

2. Discharge to springs:

Zion block

Kanab block

Paria block

Subtotal

$$
\begin{aligned}
& \overline{8,140} \\
& { }^{5,8} 840 \\
& { }^{4} 1,500
\end{aligned}
$$
4. Discharge as evapotranspiration (Kanab block only)

$$
\text { Total }=50,280-68,180
$$

'From Johns, Alice, National Park Service, Water Resources Division, written cormun. (1988).

${ }^{2}$ From Stolp, B.J., U.S. Geological Survey, written commun. (1988).

${ }^{3}$ From Cordova (1981); Camp, Dresser, and McKee, Inc., (1987, 1988a, 1988b, 1988c).

${ }_{5}^{4}$ From Freethey (1988, p. 29-34).

${ }^{5}$ From Latham, Bob, Town of Fredonia, written commun. (1988).

${ }^{6}$ From Inglis, Rick, National Park Service, Water Resources Division, written commun. (1988).

From National Park Service, written commun. (1988).

${ }^{8}$ From Hooper and Schwarting (1981, 1982a, 1982b); Johnson, Hooper, and others (1985); Johnson and others (1988); Johnson, Brent, Utah Department of Natural Resources, oral commun. (1988); Griffiths, S., Mt. Carmel Special Water District, oral commun. (1988); Golden, S., Town of Orderville Water System, oral cammun. (1988). 
Infiltration from precipitation on the exposed outcrop of the Navajo Sandstone is the principal source of recharge to the aquifer. On the basis of information obtained from U.S. Weather Bureau (1963b, 1963c) precipitation maps, the Navajo Sandstone outcrop area of approximately $790 \mathrm{mi}^{2}$ within the study area receives about 550,000 acre-ft/yr of precipitation (or approximately 410,000 acre-ft during October to April). This corresponds to a normal annual precipitation of 13.0 in. (9.7 in. from October to April).

Blanchard (1986, p. 17) suggested that most recharge to the aquifers occurs from snowmelt, which has more time for infiltration than summer precipitation that generally occurs as intense thunderstorms of short duration. This is supported by infiltration studies in the Navajo Sandstone of the lower Dirty Devil River basin, Utah, about 100 miles to the east, where isotopic analysis of deuterium and oxygen-18 indicate that recharge to the Navajo aquifer occurs primarily between fall and early spring (Danielson and Hood, 1984 , p. 1).

Because of the effects of runoff, evapotranspiration, and seasonal variations in precipitation, previous investigators have suggested values of infiltration from precipitation ranging from 1 to 20 percent of annual precipitation (Freethey, 1988, p. 26). Using this range, the quantity of possible recharge from precipitation is from 5,500 to 110,000 acre-ft/yr.

Surficial geologic heterogeneities such as fracturing, topographic relief, alluvial deposits, and basalt flows may locally affect infiltration percentages. The extent of these features and their impact on recharge could not be quantified within the scope of this study; however, there are some general trends within the study area: (1) The actual recharge percentage may be smaller than estimated for the west side of the study area because of the increased runoff caused by high topographic relief; (2) the actual recharge percentage may be greater than estimated for the central and eastern parts of the study area because of more gentle topography and larger areas of alluvial and eolian deposits covering the Navajo Sandstone outcrop, causing temporary storage of water that would allow for greater recharge rates; and (3) highly fractured regions of the Navajo Sandstone outcrop and basalt flows capping the Navajo Sandstone (such as in the northwest part of Zion National Park) may cause much larger localized recharge to the aquifer.

Seepage from streams traversing the Navajo Sandstone outcrop also is an important source of ground-water recharge. Perennial streams, including Kanab Creek, the North and East Forks Virgin River, and the Paria River, are assumed to be the predominant sources of recharge from stream seepage. Additional seepage to the aquifer may occur from ephemeral streams. Stream-discharge measurement data are needed to determine the quantity of seepage that occurs from each stream.

Seepage studies have been completed for the North and East Forks Virgin River by the National Park Service and the U.S. Geological Survey, but there are no seepage data for Kanab Creek and the Paria River. Seepage from the North and East Forks Virgin River occurs as the streams cross the upper unsaturated parts of the Navajo Sandstone (pl. 1). Two studies of the North Fork Virgin River indicated a range fram 500 to 1,600 acre-ft/yr of recharge 
from streams to the aquifer along a 7-mi reach of the river (A. Johns, National Park Service, written commun., 1988). A study of the East Fork Virgin River indicated a recharge to the aquifer of 2,300 acre-ft/yr along a 6-mi reach of the river. Because Kanab Creek has a smaller drainage area than either the North or East Fork Virgin River and because precipitation falling in the headwaters of Kanab Creek is less than the Virgin River drainage, it was estimated that recharge to the Navajo aquifer from Kanab Creek is less than 400 acre-ft/yr along a $7-\mathrm{mi}$ reach.

Other possible sources of recharge to the Navajo aquifer that have not yet been verified include vertical movement from overlying and underlying formations and inflow through faults. The consideration of downward vertical movement through the Carmel confining unit was discussed in the subsection titled "Ground-Water Movement." It also is possible that upward vertical movement through the Kayenta confining unit may occur, especially along major fault zones and in natural discharge areas. Inflow along faults also is a possibility, particularly where the Navajo aquifer is in contact with other water-bearing formations because of vertical offset along the fault. Neither water-level nor water-quality data are available to substantiate such possibilities.

\section{Sources of Discharge from the Navajo Aquifer}

Seepage of ground water to streams accounts for the largest quantity of known discharge from the Navajo aquifer. Seepage studies have indicated that between 39,800 and 57,700 acre-ft/yr of ground-water discharge to the North and East Forks of the Virgin River (pl. 1) and to Kanab Creek. Five seepage studies of the North Fork Virgin River between 1986 and 1988 indicate stream gains from 14,500 to 28,000 acre-ft/yr (A. Johns, National Park Service, written commun., 1988; B. Stolp, U.S. Geological Survey, written commun., 1988). Four seepage studies along the East Fork Virgin River during 1987 and 1988 indicate stream gains from 23,700 to 26,000 acre-ft/yr (A. Johns, National Park Service, written cormun., 1988). Stream-gage measurements and hydrograph base-flow analyses for Kanab Creek indicate a net discharge from the aquifer to the stream from 1,600 to 3,700 acre-ft/yr, although these values contain an unknown quantity of recharge from the stream to the aquifer (Cordova, 1981; Camp Dresser and McKee Inc., 1987, 1988a, 1988b, 1988c). The Paria River also is a likely discharge area for the aquifer; however, quantities are unknown. Altitudes of springs in the Paria River drainage indicate that the water levels in the Navajo aquifer are higher than the altitude of the river.

Springs also are an important source of discharge of water from the Navajo aquifer. More than 400 springs have been identified in the study area (Freethey, 1988, p. 29-34; Zion National Park, written commun., 1988; B. Latham, Town of Fredonia, written commun., 1988; R. Inglis, National Park Service, written commun., 1988). Total spring discharge is estimated to be 8,140 acre-ft/yr for the study area and consists of 3,000 acre-ft/yr in the Zion block, 5,100 acre-ft/yr in the Kanab block, and 40 acre-ft/yr in the Paria block. Because the springs were inventoried over a period of many years and during different seasons, these discharge quantities are approximate. For example, there was a steady decrease in spring discharge at Pipe Spring National Monument during 1977-88, which may reflect an overall decrease in the total monthly precipitation that was measured nearby at Kanab, Utah (fig. 7). 

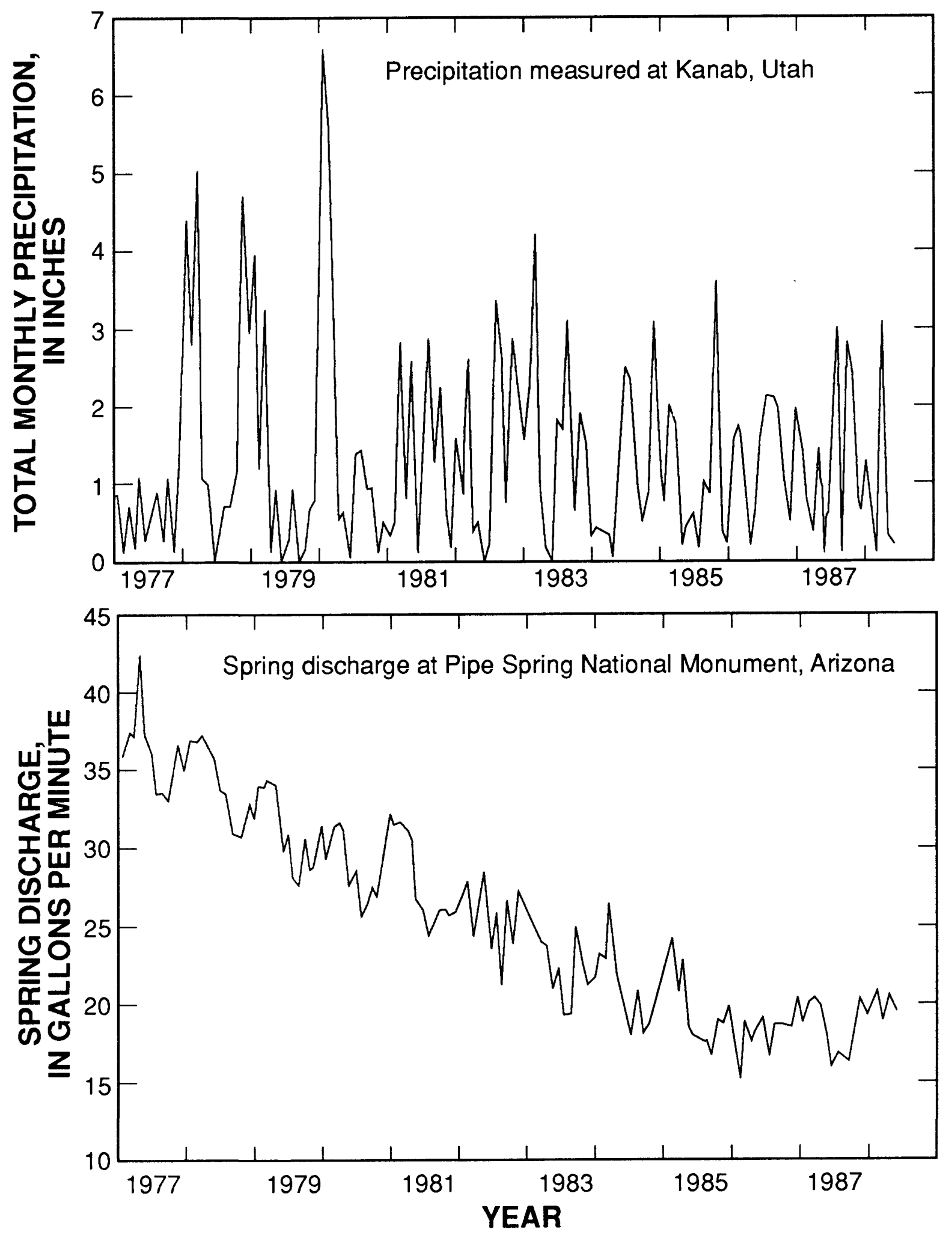

Figure 7.--Monthly precipitation at Kanab, Utah, and spring discharge at Pipe Spring National Monument, Arizona. 
Well withdrawals are a localized source of discharge near Kanab Creek, Cottonwood Canyon, and along the East Fork Virgin River in Long Valley. Discharge from wells completed in the Navajo aquifer is approximately 840 acre$\mathrm{ft} / \mathrm{yr}$. Kanab Canyon wells have the largest discharge, about 700 acre-ft/yr, and are all open to the upper Navajo aquifer except well (C-42-6)19bdc, which is open to the Lamb Point aquifer (Hooper and Schwarting, 1981, 1982a, 1982b; Johnson, Hooper, and others, 1985; Johnson and others, 1988; B. Johnson, Utah State Department of Natural Resources, oral commun., 1988). Three wells in the Indian Canyon branch of cottonwood Canyon (pl. 1) withdraw about 90 acre-ft/yr from the upper Navajo aquifer (B. Latham, Town of Fredonia, written commun., 1988). Wells at Mt. Carmel Junction, Orderville, and the east entrance of Zion National Park withdraw about 50 acre-ft/yr (S. Griffiths, Mt. Carmel Special Water District, oral commun., 1988; S. Golden, Town of Orderville Water System, oral commun., 1988). All of these quantities are approximate because well withdrawals within the study area vary through time.

Evapotranspiration, movement to overlying and underlying formations, and outflow along faults are other possible sources of ground-water discharge. Evapotranspiration occurs in most of the major canyons where phreatophytes grow (Cordova, 1981, pls. 1, 2) (pl. 1). The quantity of water discharged from the Navajo aquifer as evapotranspiration in the Kanab block was estimated to be 1,500 acre-ft/yr (Freethey, 1988, p. 29). No evapotranspiration has been estimated for the Navajo aquifer in the Zion block (Cordova, 1981, pl. 1), and no information is available for the Paria River drainage. Ground-water movement to surrounding formations and outflow along faults also are possible, but no data are available to quantify such discharges.

The total quantity of discharge from the Navajo aquifer within the study area is estimated to be between 50,280 and 68,180 acre-ft/yr. Assuming that water levels within the Navajo aquifer generally are constant, this range can be used to determine a more realistic range for recharge values.

\section{SIMULATIONS OF GROUND-WATER FLOW IN THE NAVAJO AQUIFER}

To better understand the ground-water system in the Navajo aquifer, various conceptual models were devised and tested through oomputer simulation to determine how well they represented the hydrologic system. The modular, three-dimensional, finite-difference ground-water flow model (McDonald and Harbaugh, 1988) was used to simulate ground-water movement in the Navajo aquifer within the study area.

It is assumed that the Navajo aquifer at present (1989) is in a steadystate condition. The small quantity of ground water being withdrawn does not seem to be creating any substantial overall decline in water levels. Although infiltration, which varies over time, causes seasonal and yearly fluctuations in water levels, these changes are not large (Cordova, 1981, p. 39-40; Freethey, 1988, p. 24) and, over a long period of time, tend to be relatively stable. Also, there has not been sufficient monitoring of wells or springs within the study area to allow a detailed simulation with such variations included. 


\section{Design and Construction of the Flow Model}

For computer simulation, the Navajo aquifer system was discretized into a three-dimensional grid consisting of rows, columns, and layers of cells in which aquifer properties were assumed to be uniform. The grid was oriented so that columns were approximately parallel to the major regional faults (pls. 2 and 3). The overall grid size is 92 columns by 94 rows. There are 2,642 active cells in layer 1 and 6,152 active cells in layer 2. Cell areas range in size from 0.16 to $3.74 \mathrm{mi}^{2}$.

The grid was designed to approximate the aquifer geometry and thus consists of three blocks of cells with altitudes assigned to represent the actual synclinal structure and major fault offsets (see figs. 4 and 6 ). The Zion block and the Paria block consist of one layer of cells each to represent the undivided Navajo aquifer in these areas. The Kanab block consists of two layers of cells to simulate the upper Navajo aquifer and the Lamb Point aquifer. Ground-water movement across the Tenney Canyon confining unit of the Kanab block is approximated by a vertical-leakance term rather than a separate layer because the quantity of water that the Tenney Canyon confining unit stores and transmits horizontally is negligible compared to that in overlying and underlying aquifers. In order to depict possible hydraulic connections between the three blocks, the cells in the Paria block and the upper layer of cells in the Kanab block were assigned to layer 1; the cells in the Zion block and the lower layer of cells in the Kanab block were assigned to layer 2 (fig. 8).

A vertical-leakance term was used to simulate ground-water movement through the Tenney Canyon confining unit within the Kanab block. It is defined for each cell as the vertical hydraulic conductivity divided by the thickness of the confining unit. The quantity of vertical flow through each cell is then calculated by multiplying the value of the vertical-leakance term by the area of the cell and the hydraulic-head difference between the two layers. A constant vertical-leakance value of $7.0 \times 10^{-7}$ [(ft/d)/ft] was used for all simulations. This value was determined experimentally by comparing simulated and measured water levels at two sites in the Kanab block where sets of observation wells exist for the upper Navajo aquifer and the Lamb Point aquifer. This value for vertical leakance is at the smaller end of the range of vertical-leakance values for the Tenney Canyon confining unit determined from aquifer tests at Cak Canyon $\left(5.2 \times 10^{-7}\right.$ to $\left.4.2 \times 10^{-5}[(\mathrm{ft} / \mathrm{d}) / \mathrm{ft}]\right)$. These values obtained from the Oak Canyon test are probably larger than elsewhere in the study area because the formations in the Oak Canyon area are highly fractured.

Although the Sevier Fault completely offsets the Navajo aquifer in the southern one-half of the study area, vertical flow across the fault from the upward-displaced Lamb Point aquifer of the Kanab block to the down-dropped undifferentiated Navajo aquifer of the Zion block was simulated as one possibility. In order to allow for this vertical movement in the computer simulation, special cells for the southern part of the fault were constructed (pl. 3). These cells have a uniform 100-ft thickness and were assigned 


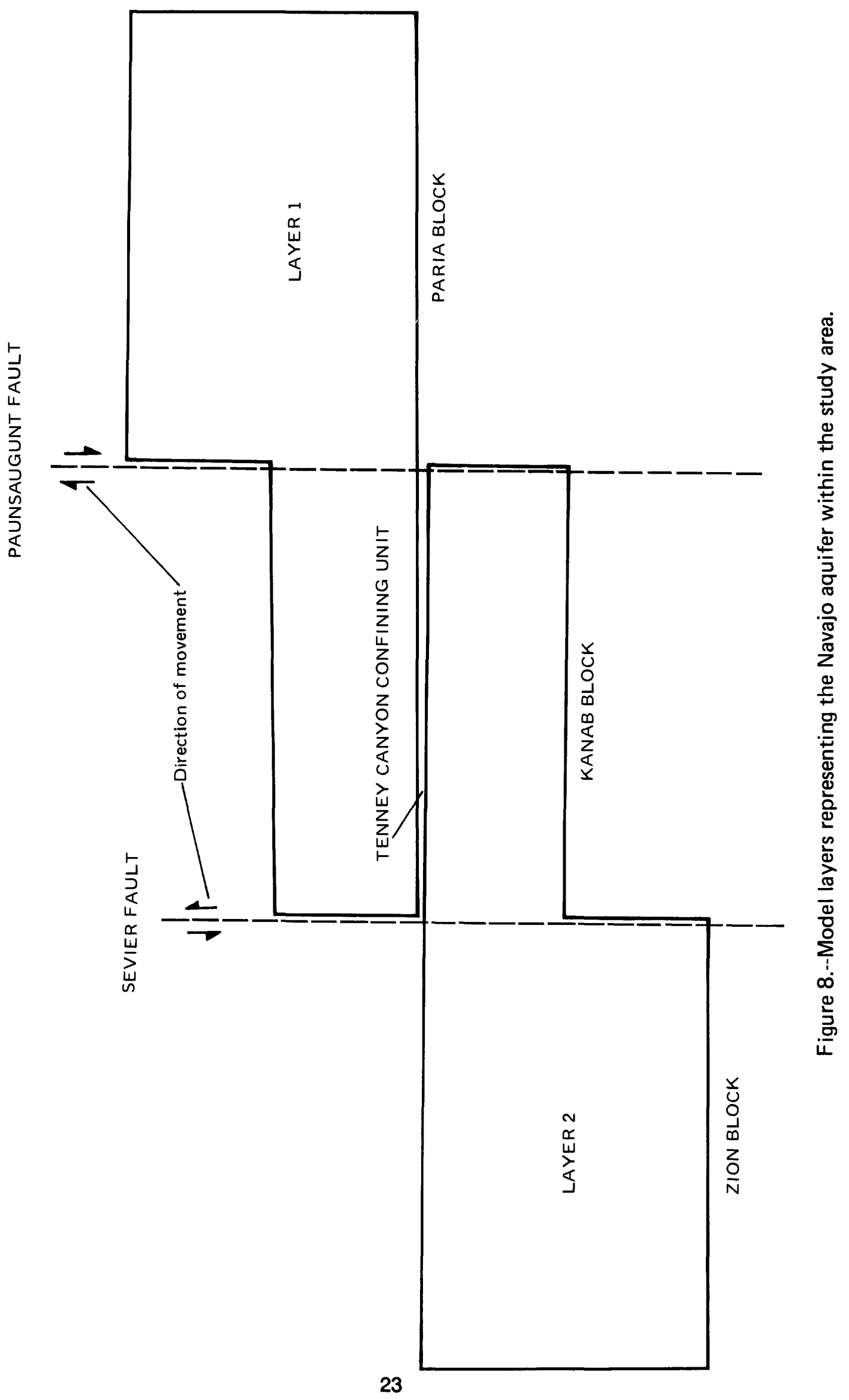


altitudes halfway between that of the bottom of the aquifer east of the fault and the top of the aquifer west of the fault. Farther north along the Sevier Fault where the aquifers are not completely offset, the actual vertical over lap was used as the thickness for these fault cells. By using these variable fault-cell thicknesses, flow was more restricted in the south where vertical offset is greater and less restricted in the north where vertical offset is less.

Three major boundaries exist for both layers of the model-lower, lateral, and upper boundaries. The lower boundary in each block is designated a no-flow boundary because of underlying, less-permeable layers. This lower boundary corresponds to the bottom of layer 2 in the Zion and Kanab blocks and to the bottom of layer 1 in the Paria block (fig. 8). The lateral boundaries of both layers are also no-flow boundaries except in layer 1 of the Paria block where the Paria River flows along part of the eastern boundary of the simulated area. Because of overlying confining units, the upper boundary of each layer is a noflow boundary except where the Navajo Sandstone crops out. Constant infiltration rates are applied to cells that represent the Navajo aquifer under the outcrop area, making this a simulated constant-flux boundary.

\section{Simulation of Recharge and Discharge}

Four packages for the modular model (Recharge, River, Drain, and Well) (McDonald and Harbaugh, 1988) were used to simulate recharge from infiltrat ing precipitation, stream seepage, spring discharge, and well withdrawals. Evapotranspiration was considered minimal and was subtracted from the value for infiltrating precipitation at the appropriate model cells.

Recharge from infiltrating precipitation (Recharge Package) was simulated by applying a constant recharge rate to cells representing the Navajo aquifer under the outcrop area. The quantity of recharge simulated was approximately 55,000 acre-ft/yr and was kept constant for all simulations. This recharge was applied to approximately $2,400 \mathrm{cells}$ that correspond to the $790 \mathrm{mi}^{2}$ of exposed outcrop within the study area (pls. 2 and 3) Infiltration rates ranged from 0.6 to $3.7 \mathrm{in} / \mathrm{yr}$ and were based on a percentage of winter precipitation (U.S. Weather Bureau, 1963b, 1963c).

The hydraulic connection between aquifers and streams was simulated with the River Package. River cells simulate either removal of water from the aquifer or addition of water to the aquifer. The direction and quantity of flow is determined by the difference between the altitude of the surface of the stream and the altitude of the potentiometric surface in the same cell, as well as the stream-bed conductance (defined as the vertical hydraulic conductivity of the stream-bed material multiplied by the area of the stream bed and divided by the thickness of the stream-bed material). Thus, simulated gaining and losing sections of the streams are a function of whether the difference between stream altitude and aquifer head is positive or negative. Seventy-two river cells were used to simulate stream gains and losses: 22 cells for the North Fork of the Virgin River, 21 cells for the East Fork Virgin River, 24 cells for Kanab Creek, and 5 cells for the Paria River (pls. 2 and 3).

Discharge from springs was simulated with the Drain Package. Drain cells are similar to river cells except that drain cells can only discharge water, and they will become inactive if the altitude of the potenticmetric surface 
drops below the altitude of the spring. Cells where spring discharge is simulated are assigned a drain-conductance value. The quantity of discharge is defined as the difference between the altitude of the potentiometric surface and the altitude of the spring multiplied by the drain-conductance value. A drain-conductance value of $800 \mathrm{ft}^{2} / \mathrm{d}$ was used at all drain cells for all of the simulations. Seventy-nine drain cells were used to simulate spring discharge: 6 drain cells are in the Paria block, 52 drain cells are in the Kanab block, and 21 drain cells are in the Zion block (pls. 2 and 3 ).

Discharge from wells was simulated in 11 cells (pls. 2 and 3 ) using the Well Package. The rate of withdrawal at each of these cells was given as the average pumping rates described in the subsection entitled "Sources of Discharge from the Navajo Aquifer." These rates remained unchanged for all steady-state simulations and accounted for a total withdrawal of 840 acre$\mathrm{ft} / \mathrm{yr}$.

\section{Alternative Steady-State Simulations}

After examining the results from numerous simulations, it became evident that horizontal hydraulic-conductivity values assigned to the aquifer cells and hydrologic properties assigned to cells representing the Sevier Fault had a major effect on ground-water movement within the Navajo aquifer. Restricting or permitting flow across the fault in layer 2 between the Zion block and the Kanab block greatly altered the direction and rate of ground-water movement. Three alternative concepts regarding flow across the Sevier Fault were devised and tested: (1) Flow across the fault remains unrestricted over its entire length; (2) flow is restricted over the entire length of the fault such that it acts as a no-flow boundary; (3) flow across the northern one-half of the fault is unrestricted, but the fault acts as a no-flow boundary for the southern onehalf where the aquifer is completely offset.

\section{Alternative 1-Unrestricted Flow Across the Sevier Fault}

In this first simulation, flow across the Sevier Fault in layer 2 was represented by the specially designated fault cells described in the section entitled "Design and Construction of the Flow Model." A uniform hydraulic conductivity of $1.5 \mathrm{ft} / \mathrm{d}$ was assigned to both layers. When larger values of hydraulic conductivity were used, the model would not reach a numerical solution. However, using a hydraulic conductivity of $1.5 \mathrm{ft} / \mathrm{d}$, tended to slow the simulated movement of ground water from recharge areas to discharge areas, resulting in a poor match between actual hydrologic conditions and simulated conditions. In order to account for preferential flow in the north-northwest direction because of jointing, a column-to-row anisotropy factor of 1.2 to 1.0 for horizontal hydraulic conductivity was used. Also, to achieve convergence, variable stream-bed conductance values were needed for the river cells simulating stream gains and losses.

The simulation of unrestricted flow across the Sevier Fault was slow to converge to a numerical solution, and the resulting water levels and water budget displayed the largest variation from the known hydrologic data (tables 2 and 3). The Modular-Model Statistical Package (J. Scott, U.S. Geological Survey, written commun., 1989) was used to analyze the match between simulated and measured water levels at 49 cells where observation wells are located. 
Table 2.-Measured and simulated water levels in selected wells

[For grid cells having more than one well, the measured water level is an average of all the wells in the cell.

Block location: P, Paria; K, Kanab; Z, Zion. All water-level altitudes are in feet above sea level; the difference between simulated and measured water levels is in feet; $R$ indicates half range]

\begin{tabular}{|c|c|c|c|c|c|c|c|c|c|c|c|}
\hline $\begin{array}{l}\text { Approximate } \\
\text { location }\end{array}$ & $\begin{array}{l}\text { Block } \\
\text { location }\end{array}$ & $\frac{\text { Grid }}{\text { Layer }}$ & $\frac{\text { loca }}{\text { Row }}$ & $\frac{\text { tion }}{\text { colum }}$ & $\begin{array}{l}\text { Measured } \\
\text { water- } \\
\text { level } \\
\text { altitude }\end{array}$ & $\begin{array}{l}\text { Alternative } \\
\text { Simulated } \\
\text { water-level } \\
\text { altitude }\end{array}$ & $\begin{array}{l}\text { number } 1 \\
\text { Simulated } \\
\text { minus } \\
\text { measured }\end{array}$ & $\begin{array}{l}\text { Alternative } \\
\text { Simulated } \\
\text { water-level } \\
\text { altitude }\end{array}$ & $\begin{array}{c}\text { number } 2 \\
\text { Simulated } \\
\text { minus } \\
\text { measured }\end{array}$ & $\begin{array}{l}\text { Alternative } \\
\text { Simulated } \\
\text { water-level } \\
\text { altitude }\end{array}$ & $\begin{array}{l}\text { number } 3 \\
\text { Simulated } \\
\text { minus } \\
\text { measured }\end{array}$ \\
\hline 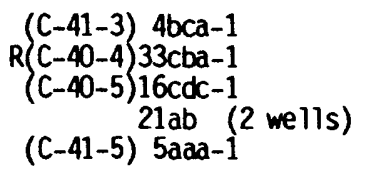 & $\begin{array}{l}P \\
K \\
K \\
K \\
K\end{array}$ & $\begin{array}{l}1 \\
1 \\
1 \\
1 \\
1\end{array}$ & $\begin{array}{l}22 \\
31 \\
32 \\
32 \\
39\end{array}$ & $\begin{array}{l}87 \\
77 \\
65 \\
66 \\
68\end{array}$ & $\begin{array}{l}5,646 \\
5,507 \\
5,394 \\
5,397 \\
5,330\end{array}$ & $\begin{array}{l}5,848 \\
5,515 \\
5,468 \\
5,471 \\
5,489\end{array}$ & $\begin{array}{l}+202 \\
+8 \\
+74 \\
+74 \\
+159\end{array}$ & $\begin{array}{l}5,715 \\
5,515 \\
5,505 \\
5,505 \\
5,505\end{array}$ & $\begin{array}{l}+69 \\
+8 \\
+111 \\
+108 \\
+175\end{array}$ & $\begin{array}{l}5,688 \\
5,437 \\
5,424 \\
5,424 \\
5,433\end{array}$ & $\begin{array}{l}+42 \\
-70 \\
+30 \\
+27 \\
+103\end{array}$ \\
\hline $\begin{array}{r}26 \mathrm{dac}-1 \\
(\mathrm{C}-42-5) 15 \mathrm{bcc}-1 \\
21 \mathrm{dda}-3 \\
30 \mathrm{ada}-1 \\
(\mathrm{C}-42-6) 21 \mathrm{ddb}-1\end{array}$ & $\begin{array}{l}K \\
K \\
K \\
K \\
K\end{array}$ & $\begin{array}{l}1 \\
1 \\
1 \\
1 \\
1\end{array}$ & $\begin{array}{l}44 \\
49 \\
52 \\
55 \\
59\end{array}$ & $\begin{array}{l}76 \\
76 \\
77 \\
75 \\
66\end{array}$ & $\begin{array}{l}5,465 \\
5,446 \\
5,457 \\
5,694 \\
5,411\end{array}$ & $\begin{array}{l}5,546 \\
5,536 \\
5,528 \\
5,564 \\
5,405\end{array}$ & $\begin{array}{l}+81 \\
+90 \\
+71 \\
-130 \\
-6\end{array}$ & $\begin{array}{l}5,513 \\
5,493 \\
5,480 \\
5,477 \\
5,330\end{array}$ & $\begin{array}{l}+48 \\
+47 \\
+23 \\
-217 \\
-81\end{array}$ & $\begin{array}{l}5,455 \\
5,457 \\
5,503 \\
5,446 \\
5,314\end{array}$ & $\begin{array}{l}-10 \\
+11 \\
+46 \\
-248 \\
-97\end{array}$ \\
\hline 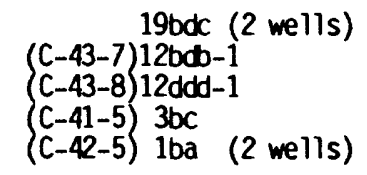 & $\begin{array}{l}K \\
K \\
K \\
K \\
K\end{array}$ & $\begin{array}{l}1 \\
1 \\
1 \\
2 \\
2\end{array}$ & $\begin{array}{l}61 \\
70 \\
77 \\
45 \\
45\end{array}$ & $\begin{array}{l}61 \\
62 \\
51 \\
77 \\
78\end{array}$ & $\begin{array}{l}5,459 \\
5,796 \\
6,100 \\
5,430 \\
5,491\end{array}$ & $\begin{array}{l}5,437 \\
5,620 \\
5,860 \\
5,499 \\
5,510\end{array}$ & $\begin{array}{l}-22 \\
-176 \\
-240 \\
+69 \\
+19\end{array}$ & $\begin{array}{l}5,387 \\
5,536 \\
5,833 \\
5,481 \\
5,484\end{array}$ & $\begin{array}{r}-72 \\
-260 \\
-267 \\
+51 \\
-7\end{array}$ & $\begin{array}{l}5,365 \\
5,533 \\
5,823 \\
5,429 \\
5,433\end{array}$ & $\begin{array}{l}-94 \\
-263 \\
-277 \\
-\quad 1 \\
-58\end{array}$ \\
\hline 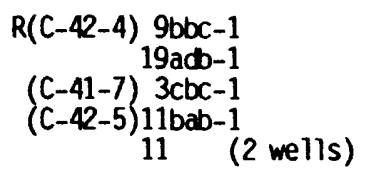 & $\begin{array}{l}k \\
k \\
Z \\
k \\
K\end{array}$ & $\begin{array}{l}2 \\
2 \\
2 \\
2 \\
2\end{array}$ & $\begin{array}{l}45 \\
46 \\
47 \\
47 \\
47\end{array}$ & $\begin{array}{l}81 \\
85 \\
44 \\
77 \\
78\end{array}$ & $\begin{array}{l}5,501 \\
5,565 \\
5,282 \\
5,443 \\
5,437\end{array}$ & $\begin{array}{l}5,552 \\
5,638 \\
5,144 \\
5,488 \\
5,497\end{array}$ & $\begin{array}{l}+51 \\
+73 \\
-138 \\
+45 \\
+60\end{array}$ & $\begin{array}{l}5,497 \\
5,531 \\
4,972 \\
5,467 \\
5,469\end{array}$ & $\begin{array}{l}-4 \\
-34 \\
-310 \\
+24 \\
+32\end{array}$ & $\begin{array}{l}5,449 \\
5,595 \\
5,013 \\
5,424 \\
5,428\end{array}$ & $\begin{array}{l}-52 \\
+30 \\
-269 \\
-19 \\
-\quad 9\end{array}$ \\
\hline $\begin{array}{r}11 c d \\
15 b d c-1 \\
14 c b \\
23 b b b-1 \\
(C-41-7) 18 d c a-1\end{array}$ & $\begin{array}{l}K \\
K \\
K \\
K \\
Z\end{array}$ & $\begin{array}{l}2 \\
2 \\
2 \\
2 \\
2\end{array}$ & $\begin{array}{l}48 \\
49 \\
49 \\
50 \\
52\end{array}$ & $\begin{array}{l}78 \\
77 \\
78 \\
78 \\
41\end{array}$ & $\begin{array}{l}5,435 \\
5,372 \\
5,388 \\
5,437 \\
4,945\end{array}$ & $\begin{array}{l}5,487 \\
5,473 \\
5,477 \\
5,466 \\
5,108\end{array}$ & $\begin{array}{l}+52 \\
+101 \\
+89 \\
+29 \\
+163\end{array}$ & $\begin{array}{l}5,460 \\
5,451 \\
5,450 \\
5,441 \\
4,967\end{array}$ & $\begin{array}{l}+25 \\
+79 \\
+62 \\
+4 \\
+22\end{array}$ & $\begin{array}{l}5,423 \\
5,417 \\
5,419 \\
5,414 \\
4,995\end{array}$ & $\begin{array}{l}-12 \\
+45 \\
+31 \\
-23 \\
+50\end{array}$ \\
\hline 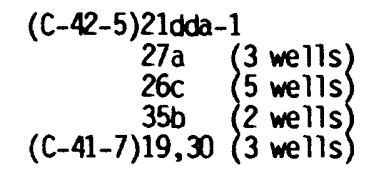 & $\begin{array}{l}K \\
K \\
K \\
K \\
Z\end{array}$ & $\begin{array}{l}2 \\
2 \\
2 \\
2 \\
2\end{array}$ & $\begin{array}{l}52 \\
52 \\
53 \\
54 \\
55\end{array}$ & $\begin{array}{l}77 \\
78 \\
79 \\
79 \\
41\end{array}$ & $\begin{array}{l}5,403 \\
5,391 \\
5,381 \\
5,473 \\
4,960\end{array}$ & $\begin{array}{l}5,453 \\
5,445 \\
5,417 \\
5,414 \\
5,099\end{array}$ & $\begin{array}{l}+50 \\
+54 \\
+36 \\
-59 \\
+139\end{array}$ & $\begin{array}{l}5,430 \\
5,423 \\
5,405 \\
5,401 \\
4,968\end{array}$ & $\begin{array}{l}+27 \\
+32 \\
+24 \\
-72 \\
+8\end{array}$ & $\begin{array}{l}5,406 \\
5,403 \\
5,393 \\
5,391 \\
4,992\end{array}$ & $\begin{array}{l}+3 \\
+12 \\
+12 \\
+82 \\
+32\end{array}$ \\
\hline $\begin{array}{c}(C-42-5) 34,35 \text { (2 wells) } \\
35 \mathrm{ca} \\
(C-43-5) 2 \mathrm{~b} \quad \text { (3 wells) } \\
12 \mathrm{bdc}-1 \\
(C-42-6) 19 \mathrm{baa}-1\end{array}$ & $\begin{array}{l}K \\
K \\
K \\
K \\
K\end{array}$ & $\begin{array}{l}2 \\
2 \\
2 \\
2 \\
2\end{array}$ & $\begin{array}{l}55 \\
55 \\
56 \\
58 \\
60\end{array}$ & $\begin{array}{l}79 \\
80 \\
80 \\
82 \\
61\end{array}$ & $\begin{array}{l}5,365 \\
5,318 \\
5,355 \\
5,240 \\
5,494\end{array}$ & $\begin{array}{l}5,408 \\
5,389 \\
5,376 \\
5,428 \\
5,332\end{array}$ & $\begin{array}{l}+43 \\
+71 \\
+21 \\
+188 \\
-162\end{array}$ & $\begin{array}{l}5,396 \\
5,383 \\
5,372 \\
5,403 \\
5,391\end{array}$ & $\begin{array}{l}+31 \\
+65 \\
+17 \\
+163 \\
-103\end{array}$ & $\begin{array}{l}5,388 \\
5,376 \\
5,366 \\
5,407 \\
5,363\end{array}$ & $\begin{array}{l}+23 \\
+58 \\
+11 \\
+167 \\
-131\end{array}$ \\
\hline $\begin{array}{c}(\mathrm{C}-41-8) 35 \mathrm{cca}-1 \\
(\mathrm{C}-42-6) 19 \mathrm{bdc}-3 \\
30 \mathrm{baa}-1 \\
30 \mathrm{dcb}-1 \\
\text { 30cda (2 wells) }\end{array}$ & $\begin{array}{l}Z \\
K \\
K \\
K \\
K\end{array}$ & $\begin{array}{l}2 \\
2 \\
2 \\
2 \\
2\end{array}$ & $\begin{array}{l}61 \\
61 \\
62 \\
63 \\
64\end{array}$ & $\begin{array}{l}39 \\
61 \\
62 \\
63 \\
62\end{array}$ & $\begin{array}{l}4,958 \\
5,277 \\
5,241 \\
5,265 \\
5,242\end{array}$ & $\begin{array}{l}5,053 \\
5,314 \\
5,322 \\
5,291 \\
5,303\end{array}$ & $\begin{array}{l}+95 \\
+37 \\
+81 \\
+26 \\
+61\end{array}$ & $\begin{array}{l}4,966 \\
5,375 \\
5,378 \\
5,333 \\
5,349\end{array}$ & $\begin{array}{l}+8 \\
+98 \\
+137 \\
+68 \\
+107\end{array}$ & $\begin{array}{l}4,979 \\
5,350 \\
5,355 \\
5,315 \\
5,332\end{array}$ & $\begin{array}{l}+21 \\
+73 \\
+114 \\
+50 \\
+90\end{array}$ \\
\hline
\end{tabular}


Table 2.-Measured and simulated water levels in selected wells--Continued

\begin{tabular}{|c|c|c|c|c|c|c|c|c|c|c|c|}
\hline $\begin{array}{l}\text { Approximate } \\
\text { location }\end{array}$ & $\begin{array}{l}\text { Block } \\
\text { location }\end{array}$ & $\frac{\text { Grid }}{\text { Layer }}$ & $\frac{d \text { loca }}{\text { Row }}$ & $\frac{\text { tion }}{\text { colum }}$ & $\begin{array}{l}\text { Measured } \\
\text { water- } \\
\text { level } \\
\text { altitude }\end{array}$ & $\begin{array}{l}\text { Alternative } \\
\text { Simulated } \\
\text { water-level } \\
\text { altitude }\end{array}$ & $\begin{array}{l}\text { number } 1 \\
\text { Simulated } \\
\text { minus } \\
\text { measured }\end{array}$ & $\begin{array}{l}\text { Alternative } \\
\text { Simulated } \\
\text { water-level } \\
\text { altitude }\end{array}$ & $\begin{array}{l}\text { number } 2 \\
\text { Simulated } \\
\text { minus } \\
\text { measured }\end{array}$ & $\begin{array}{l}\text { Alternative } \\
\text { Simulated } \\
\text { water-level } \\
\text { altitude }\end{array}$ & $\begin{array}{l}\text { number } 3 \\
\text { Símulated } \\
\text { minus } \\
\text { measured }\end{array}$ \\
\hline $\begin{array}{l}\left(\begin{array}{l}C-41-9) 20 \mathrm{bdb}-1 \\
C-42-7 \\
C\end{array} 25 \mathrm{dcb}-1\right. \\
(C-42-6) 31,32 \text { (2 wells) } \\
(C-43-6) 5 \mathrm{ada}-1 \\
(C-42-7) 19 \mathrm{bdd}-1\end{array}$ & $\begin{array}{l}Z \\
K \\
K \\
K \\
Z\end{array}$ & $\begin{array}{l}2 \\
2 \\
2 \\
2 \\
2\end{array}$ & $\begin{array}{l}65 \\
65 \\
65 \\
66 \\
67\end{array}$ & $\begin{array}{l}27 \\
60 \\
64 \\
67 \\
47\end{array}$ & $\begin{array}{l}4,830 \\
5,260 \\
5,173 \\
5,210 \\
5,090\end{array}$ & $\begin{array}{l}4,938 \\
5,350 \\
5,272 \\
5,245 \\
5,182\end{array}$ & $\begin{array}{l}+108 \\
+90 \\
+99 \\
+35 \\
+92\end{array}$ & $\begin{array}{l}4,863 \\
5,403 \\
5,301 \\
5,250 \\
5,020\end{array}$ & $\begin{array}{l}+33 \\
+143 \\
+128 \\
+40 \\
-70\end{array}$ & $\begin{array}{l}4,878 \\
5,385 \\
5,289 \\
5,243 \\
5,029\end{array}$ & $\begin{array}{l}+48 \\
+125 \\
+116 \\
+33 \\
-61\end{array}$ \\
\hline $\begin{array}{c}(c-43-7) 16 b c c-1 \\
16 b d d-1 \\
16 d b \text { (2 wells) } \\
(c-43-8) 34 \text { bbb-1 }\end{array}$ & $\begin{array}{l}K \\
K \\
K \\
Z\end{array}$ & $\begin{array}{l}2 \\
2 \\
2 \\
2\end{array}$ & $\begin{array}{l}76 \\
76 \\
77 \\
82\end{array}$ & $\begin{array}{l}56 \\
57 \\
57 \\
48\end{array}$ & $\begin{array}{l}5,609 \\
5,589 \\
5,595 \\
5,078\end{array}$ & $\begin{array}{l}5,575 \\
5,592 \\
5,596 \\
5,411\end{array}$ & $\begin{array}{l}-34 \\
+\quad 3 \\
+1 \\
+333\end{array}$ & $\begin{array}{l}5,655 \\
5,648 \\
5,668 \\
5,205\end{array}$ & $\begin{array}{l}+46 \\
+59 \\
+73 \\
+127\end{array}$ & $\begin{array}{l}5,657 \\
5,650 \\
5,672 \\
5,209\end{array}$ & $\begin{array}{l}+48 \\
+61 \\
+77 \\
+131\end{array}$ \\
\hline
\end{tabular}

Statistics of differences between measured and simulated water levels, in feet (simulated minus measured)

\begin{tabular}{|c|c|c|c|}
\hline & $\begin{array}{l}\text { Alternative } \\
\text { number } 1 \\
\end{array}$ & $\begin{array}{c}\text { Alternative } \\
\text { number } 2 \\
\end{array}$ & $\begin{array}{c}\text { Alternative } \\
\text { number } 3 \\
\end{array}$ \\
\hline Arithmetic mean & +43 & +16 & -1 \\
\hline Median & +52 & +31 & +21 \\
\hline Standard deviation & 96 & 102 & 98 \\
\hline $\begin{array}{l}\text { Maximum difference } \\
\text { lower than measured }\end{array}$ & -240 & -310 & -277 \\
\hline $\begin{array}{l}\text { Maximum difference } \\
\text { higher than measured }\end{array}$ & +333 & +175 & +167 \\
\hline
\end{tabular}


Results indicate that the arithmetic mean of the simulated water levels was 43 ft higher than the arithmetic mean of the measured water levels. Of the 13 cells having differences of more than $100 \mathrm{ft}$ between measured and simulated water levels, the largest deviations were at 2 cells along the Sevier Fault (layer 2, row $82, \infty$ lumn 48 , difference of $+333 \mathrm{ft}$; and layer 1 , row 77 , column 51 , difference of $-240 \mathrm{ft}$ ) (table 2 ). The other 11 cells with differences larger than $100 \mathrm{ft}$ were evenly distributed and showed no particular trend. Forty of the 49 cells with measured water levels are east of the sevier Fault. Of these 40 cells, 31 had simulated water levels that were higher than measured water levels. Results show that although water was allowed to drain westward across the Sevier Fault, the small hydraulic-conductivity values caused higherthan-measured water levels in both the Kanab and Paria blocks.

The most reliable hydrologic data for the $\mathrm{Zion}$ block are the seepage studies of the North and East Forks Virgin River, which indicate that simulated water levels are higher than measured water levels. The simulated boundary between gaining and losing reaches of the East Fork, for the alternative simulating unrestricted flow across the sevier Fault, was about $4 \mathrm{mi}$ upstream of the boundary indicated by the seepage study. The simulated boundary between gaining and losing reaches on the North Fork was about $0.6 \mathrm{mi}$ upstream of that indicated by the seepage study. The locations of the gain/loss boundaries determined by the model are only accurate to about \pm 1 mile because of the cell size. Therefore, the deviation of the simulated North Fork gain/loss boundary from the observed location is not substantial. In addition to the seepage study, measured water levels in the Zion block were generally lower than simulated water levels in the corresponding model cells.

The ground-water budgets for Alternative 1 (table 3 ) indicate that simulated values for recharge from the East Fork Virgin River are too small and simulated values for discharge to springs are too large by more than 50 percent of the estimated or measured value. These two values for Alternative 1 differ more from the estimated or measured data than results from the other two alternatives.

The simulated flow of water across the Sevier and Paunsaugunt Faults also is given in table 3. Alternative 1 has a net east-to-west flow across the Sevier Fault of $10,010 \mathrm{acre}-\mathrm{ft} / \mathrm{yr}$ and a net east-to-west flow across the Paunsaugunt Fault of 3,380 acre-ft/yr.

\section{Alternative 2--No Flow Across the Sevier Fault}

In Alternative 2, no flow was simulated across the Sevier Fault. This was done by setting the hydraulic conductivity equal to zero everywhere along the fault in layer 2. By shutting off flow across the Sevier Fault, it was possible to increase hydraulic-conductivity values, which improved the match between measured and simulated water levels. In general, the hydraulic conductivity was set to $2.2 \mathrm{ft} / \mathrm{d}$ in both layers except for certain fringe cells where a value of $0.5 \mathrm{ft} / \mathrm{d}$ was assigned to avoid the propagation of dry cells. As in Alternative 1, a column-to-row anisotropy factor for horizontal hydraulic conductivity of 1.2 to 1.0 was used to approximate preferential flow due to jointing. 
Table 3.-Ground-water budgets and flow across the Sevier and Paunsaugunt Faults for the 3 alternative steady-state simulations

[A11 rates in acre-feet per year; --, not measured; <, less than]

\begin{tabular}{|c|c|c|c|c|}
\hline & $\begin{array}{c}\text { ATternative } \\
1\end{array}$ & $\frac{\text { Simulated rates }}{\text { Alternative }}$ & Atternative & $\begin{array}{l}\text { Estimated or } \\
\text { measured rates } \\
\text { (Table 1) }\end{array}$ \\
\hline \multicolumn{5}{|l|}{ Recharge } \\
\hline $\begin{array}{l}\text { 1. Recharge by precipitation on the } \\
\text { outcrop }\end{array}$ & 56,490 & 55,280 & 55,110 & $5,500-110,000$ \\
\hline $\begin{array}{l}\text { 2. Recharge from streams: } \\
\text { a) North Fork Virgin River } \\
\text { b) East Fork Virgin River } \\
\text { c) Kanab Creek }\end{array}$ & $\begin{array}{r}1,360 \\
30 \\
150 \\
\end{array}$ & $\begin{array}{l}920 \\
750 \\
150 \\
\end{array}$ & $\begin{array}{l}920 \\
590 \\
150 \\
\end{array}$ & 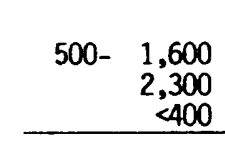 \\
\hline Total recharge: & 58,030 & 57,100 & 56,770 & $8,700-114,300$ \\
\hline \multicolumn{5}{|l|}{ Discharge } \\
\hline $\begin{array}{l}\text { 1. Discharge to streams: } \\
\text { a) North Fork Virgin River } \\
\text { b) East Fork Virgin River } \\
\text { c) Kanab Creek } \\
\text { d) Paria River }\end{array}$ & $\begin{array}{r}12,180 \\
23,150 \\
5,160 \\
3,680\end{array}$ & $\begin{array}{r}19,500 \\
20,000 \\
6,010 \\
4,180\end{array}$ & $\begin{array}{r}21,520 \\
21,440 \\
4,840 \\
2,140\end{array}$ & $\begin{array}{r}14,500-28,000 \\
23,700-26,000 \\
1,600-\quad 3,700 \\
\text { unknown }\end{array}$ \\
\hline 2. Discharge to springs & 13,040 & 6,580 & 6,020 & 8,140 \\
\hline 3. Well withdrawals & 840 & 840 & 840 & 840 \\
\hline 4. Discharge as evapotranspiration & - & - & -- & 1,500 \\
\hline Total discharge: & 58,050 & 57,110 & 56,800 & $50,280-68,180$ \\
\hline \multicolumn{5}{|l|}{ Flow across faults } \\
\hline 1. Sevier Fault (east to west) & 10,010 & 0 & 3,920 & unknown \\
\hline $\begin{array}{l}\text { 2. Paunsaugunt Fault: } \\
\text { a) East to west } \\
\text { b) West to east }\end{array}$ & $\begin{array}{r}4,190 \\
810 \\
\end{array}$ & $\begin{array}{l}1,340 \\
1,070 \\
\end{array}$ & $\begin{array}{r}2,650 \\
670 \\
\end{array}$ & unknown \\
\hline $\begin{array}{l}\text { Net east to west flow } \\
\text { (across Paunsaugunt Fault) }\end{array}$ & 3,380 & 270 & 1,980 & \\
\hline
\end{tabular}


For the simulations of Alternatives 2 and 3, stream-bed conductance values for river cells were constant for each river, and ranged from 600 to 5,500 $\mathrm{ft}^{2} / \mathrm{d}$. This range of values was smaller than the range of conductance values used for Alternative 1.

In general, eliminating flow across the Sevier Fault and increasing hydraulic conductivity of the Navajo aquifer improved the match between measured and simulated water levels (table 2). The arithmetic mean of the simulated water levels was $16 \mathrm{ft}$ higher than the mean of the measured water levels. Of the 14 cells that had simulated water levels more than $100 \mathrm{ft}$ different than measured water levels, the largest deviations were for two cells along the Sevier Fault (layer 2, row 47, column 44, difference of $-310 \mathrm{ft}$; and layer 1, row 77, column 51, difference of $-267 \mathrm{ft}$ ) (table 2). No trends were apparent in the location of the other 12 cells.

The effects within the Kanab and Paria blocks of a no-flow boundary across the Sevier Fault were offset by the increase in hydraulic conductivity from 1.5 to $2.2 \mathrm{ft} / \mathrm{d}$. Thus, rather than the increase in water levels expected by eliminating simulated discharge across the western boundary of the Kanab block, a slight decrease occurred. As in Alternative 1, 31 out of $40 \mathrm{cells}$ in the Kanab and Paria blocks had higher simulated water levels than measured water levels.

Simulated water levels in Alternative 2 were lower than in Alternative 1 at all nine cells in the Zion block, which was a notable improvement in all but one well. Completely shutting off flow across the Sevier Fault and increasing hydraulic conductivity, therefore, produced lower water levels in the zion block. Also, the simulated gain/loss boundary for the East Fork Virgin River improved substantially and occurred at a point about 1.25 miles from the observed location (pl. 1). The simulated gain/loss boundary on the North Fork Virgin River remained the same, about $0.6 \mathrm{mi}$ upstream of the observed location.

In Alternative 2, the quantities of recharge to the Navajo aquifer from the East Fork Virgin River, discharge from the Navajo aquifer to the East Fork Virgin River, and discharge from springs are less than measured. Also, the simulated quantity of discharge from the Navajo aquifer to Kanab Creek is larger than measured. The ground-water budget values for Alternative 2, however, are generally closer to measured values than those of Alternative 1 . Alternative 2 has no net flow across the Sevier Fault, and a net east-to-west flow of only 270 acre-ft/yr crossing the Paunsaugunt Fault (table 3). Thus, eliminating flow across the Sevier Fault changes ground-water flow directions and substantially decreases net flow across the Paunsaugunt Fault.

Alternative 3--Flow Only Across the Northern One-Half of the Sevier Fault

In Alternative 3, no flow was simulated across the southern one-half of the Sevier Fault. This was achieved by setting the hydraulic conductivity equal to zero in layer 2 in the cells representing the southern one-half of the fault (rows 36 through 83 ).

For the northern one-half of the fault, hydraulic conductivity was decreased linearly in cells simulating the fault from $0.4 \mathrm{ft} / \mathrm{d}$ in row 1 to 0.0 $\mathrm{ft} / \mathrm{d}$ in row 36 (pl. 3). This smaller hydraulic conductivity represents the 
decrease in flow expected to the south as fault offset increases. Elsewhere, the hydraulic conductivity was $2.2 \mathrm{ft} / \mathrm{d}$ as in Alternative 2, except for certain fringe cells that were assigned the value of $0.03 \mathrm{ft} / \mathrm{d}$ in layer 1 and $0.08 \mathrm{ft} / \mathrm{d}$ in layer 2 to avoid the propagation of dry cells. As in Alternatives 1 and 2, a column-to-row anisotropy factor for horizontal hydraulic conductivity of 1.2 to 1.0 was used to approximate preferential flow due to jointing. Also, stream-bed conductance values for river cells were constant for each river and ranged from 600 to $5,500 \mathrm{ft}^{2} / \mathrm{d}$, the same as in Alternative 2 .

Alternative 3 provided the best match between measured and simulated water levels. The arithmetic mean of the simulated water levels was $1 \mathrm{ft}$ lower than the mean of the measured water levels. Of the 11 cells that had simulated water levels more than $100 \mathrm{ft}$ different than measured water levels, the largest deviations were for the same two cells along the Sevier Fault as in Alternative 2 (layer 1, row 77, column 51, difference of $-277 \mathrm{ft}$; and layer 2, row 47 , column 44, difference of $-269 \mathrm{ft}$ ) (table 2). No trends were apparent in the location of the other nine cells.

By simulating flow across the northern one-half of the Sevier Fault, the differences between measured and simulated water levels were less in all three blocks. For Alternative 3, the number of cells in the Kanab and Paria blocks having simulated water levels that were higher than measured values decreased to 29 of 40 (in Alternatives 1 and 2, 31 of 40 cells had simulated water levels that were higher than measured values). Similarly, the water levels in seven of the nine cells in the Zion block had less difference between measured and simulated water levels than in Alternative 2. Within the Zion block, the location of the simulated gain/loss boundary of the East Fork Virgin River for Alternative 3 was about $1.25 \mathrm{mi}$ farther upstream from the measured location than the boundary simulated in Alternative 2. The gain/loss boundary on the North Fork Virgin River remained the same, at about $0.6 \mathrm{mi}$ upstream of the determined location (pl. 1).

Based on differences between estimated or measured budget components and simulated components, Alternative 3 best approximated the overall ground-water budget (table 3). Recharge to the Navajo aquifer as seepage from the East Fork Virgin River and spring discharge deviated more (quantities were too small) from measured quantities in Alternative 3 than in Alternative 2. The overall ground-water budget for Alternative 3, however, was improved because the quantity of discharge from the Navajo aquifer to the North and East Forks Virgin River and to Kanab Creek (table 3) more closely approximated estimated or measured values. The net east-to-west flow across the sevier Fault in Alternative 3 was 3,920 acre-ft/yr; net east-to-west flow across the Paunsaugunt fault was 1,980 acre-ft/yr (table 3 ).

A comparison of the water-level contours for layer 1 for the three alternative simulations (figs. 9, 10, and 11) indicates that the simulated directions of ground-water flow (perpendicular to these contours) are similar. Simulated water levels in Alternatives 1 and 3, however, are lower than in Alternative 2 in the center of layer 1 south of Bryce Canyon National Park. This is because ground water is permitted to flow across the northern part of the sevier Fault in layer 2 for these two simulations, thus allowing more water to drain from layer 1. 


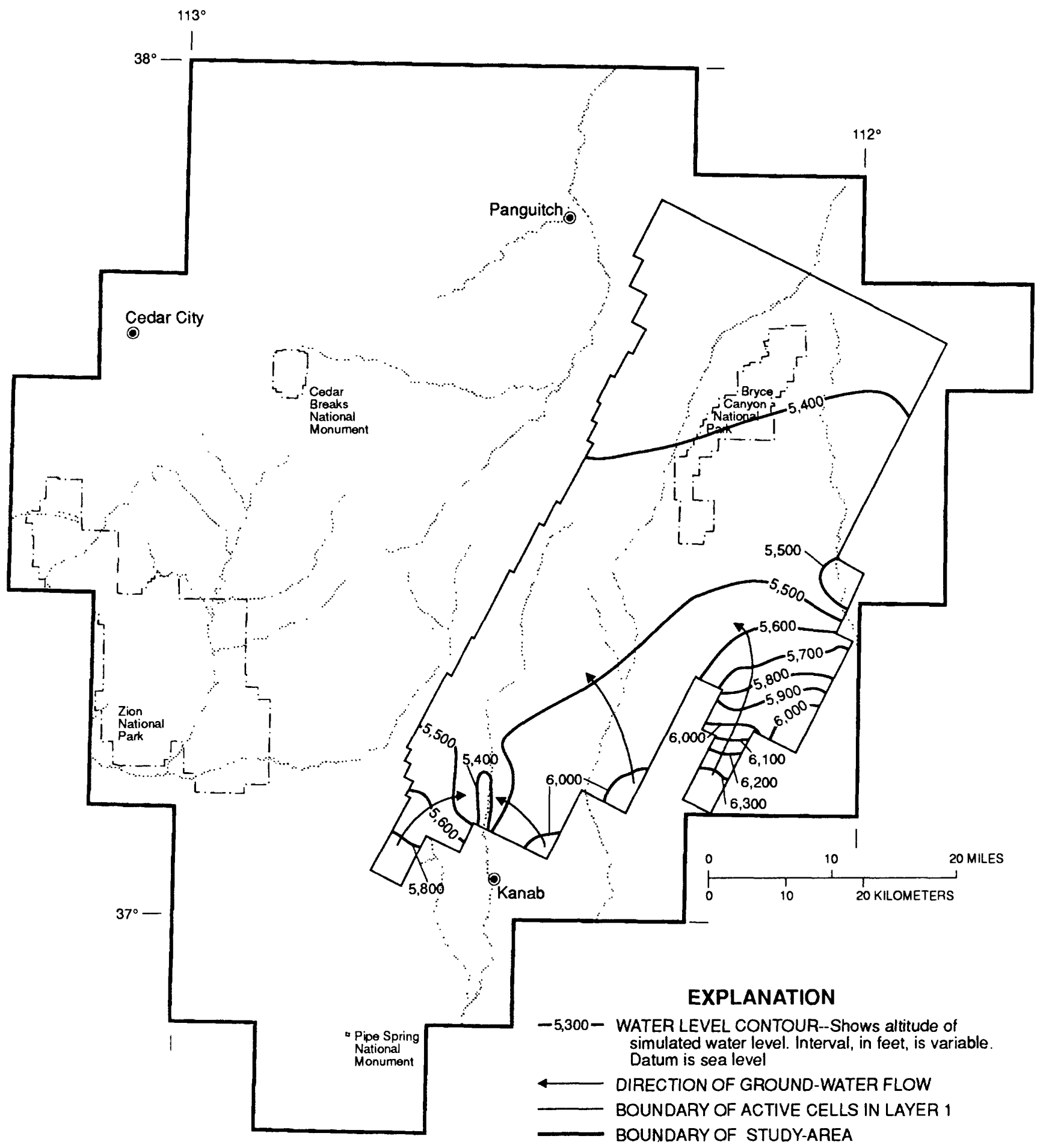

Figure 9.--Steady-state simulated water-level contours in layer 1 for Alternative 1 (unrestricted flow across the Sevier Fault). 


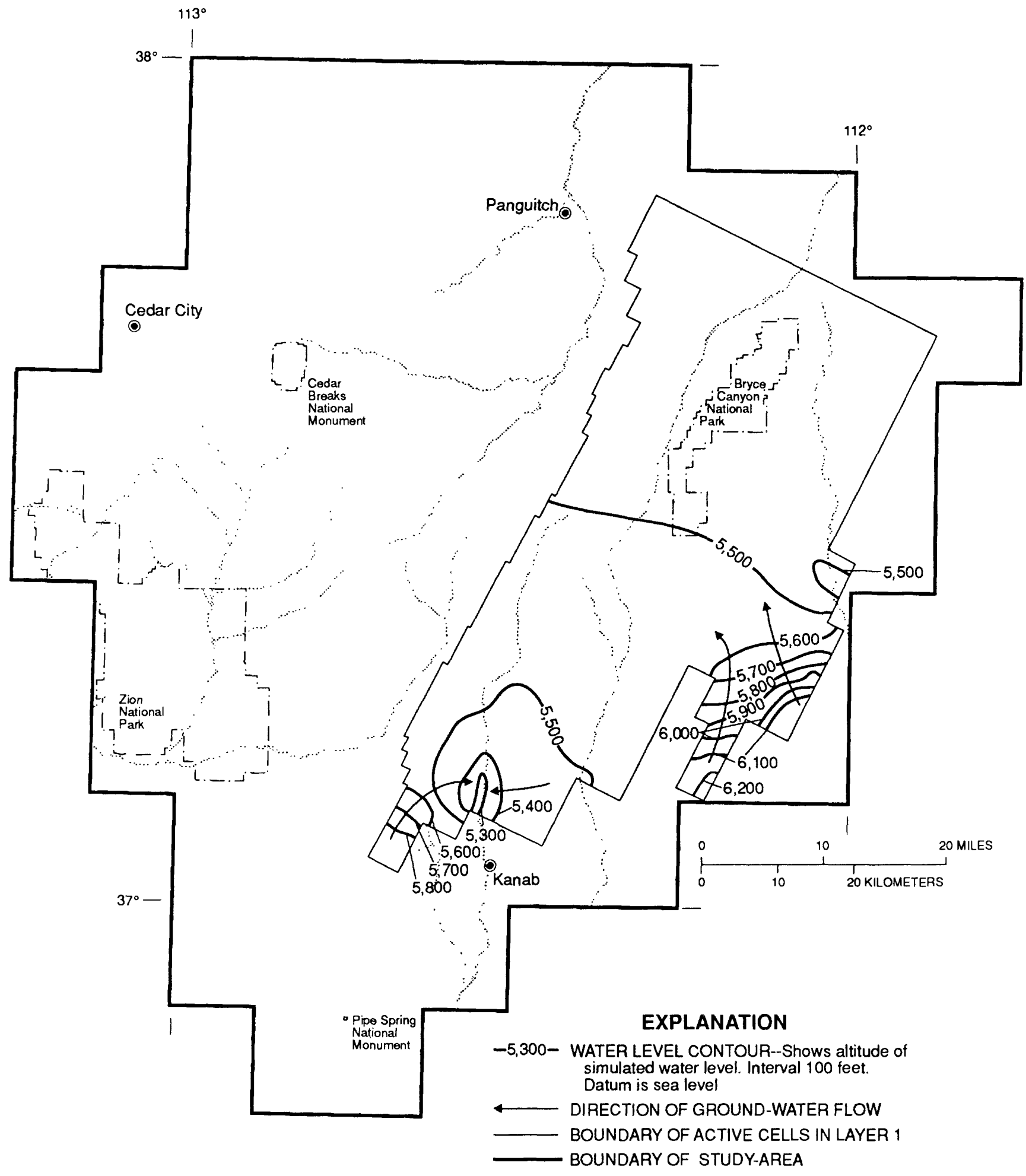

Figure 10.--Steady-state simulated water-level contours in layer 1 for Alternative 2 (no flow across the Sevier Fault). 


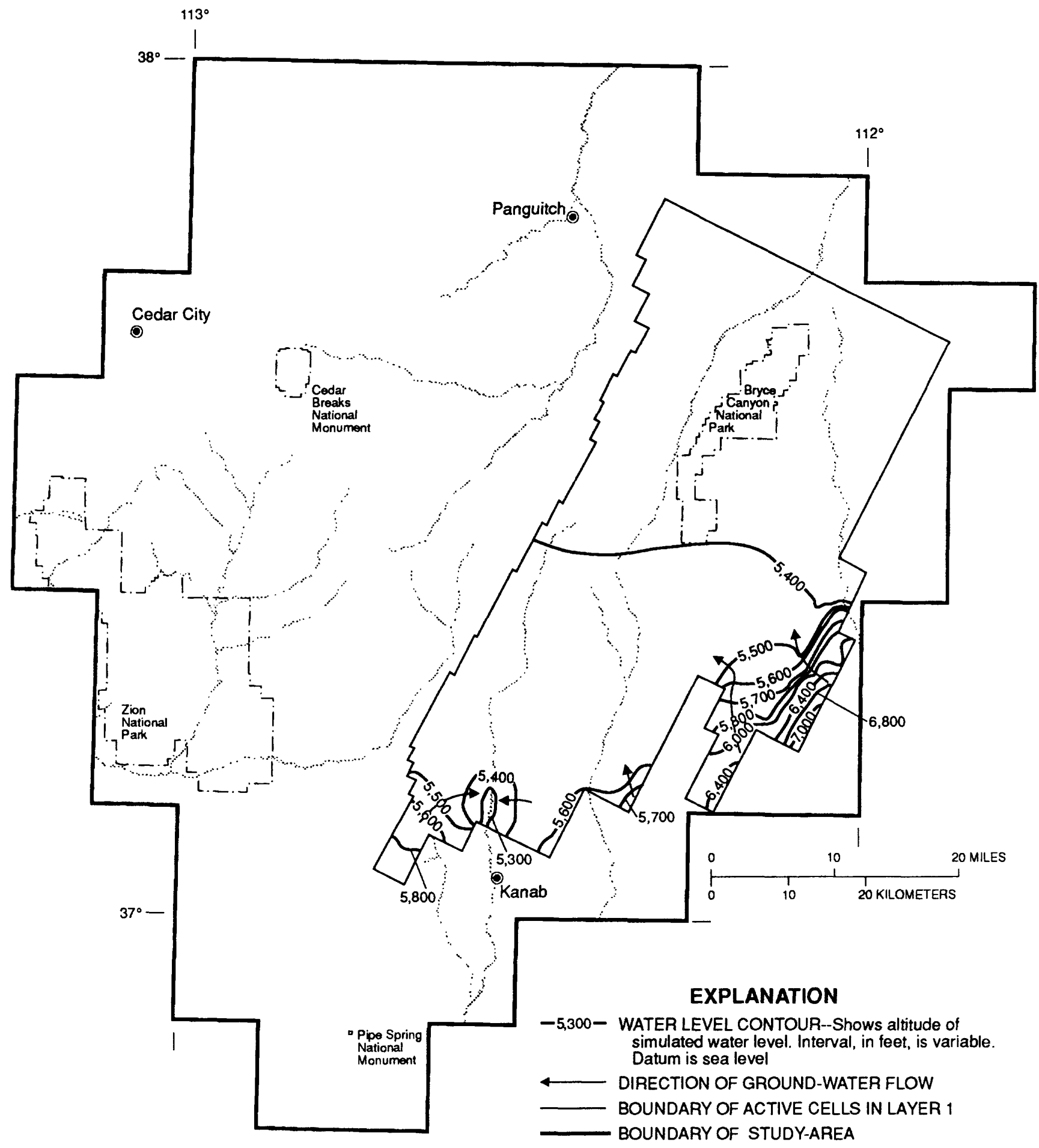

Figure 11.--Steady-state simulated water-level contours in layer 1 for Alternative 3 (partial flow across the Sevier Fault). 
Water-level contours for layer 2 in the three simulations (figs. 12, 13, and 14) are different because of the variation in hydraulic conductivity and flow conditions imposed along the Sevier Fault. Alternative 1 includes local recharge-discharge flow paths, as well as a general east-to-west component of flow across most of the area. The east-to-west flow paths exist because ground-water flow simulated was across the Sevier Fault. There are areas where the hydraulic gradient is relatively steep because of the smaller hydraulic conductivity used in Alternative 1.

Water-level contours intersect the fault perpendicularly, indicating no regional flow (fig. 13). In Alternative 2, no overall east-to-west flow was simulated due to the effects of the no-flow boundary at the sevier Fault.

Water-level contours for layer 2 of Alternative 3 (fig. 14) generally are similar to those of Alternative 1 in the northern part of the study area because of the unrestricted flow conditions for the northern one-half of the Sevier Fault in both simulations. In the southern part of the study area, however, water-level contours for layer 2 of Alternative 3 are more similar to those of Alternative 2 than to those of Alternative 1 because of the no-flow conditions for the southern one-half of the Sevier Fault and the larger values of hydraulic conductivity for Alternatives 2 and 3.

\section{Sensitivity Analysis}

Other combinations of hydrologic properties were tested to arrive at the most reasonable values used for the three alternative simulations presented previously. Various ranges of values for hydraulic conductivity and anisotropy were tested.

Except for perimeter cells and Sevier Fault cells, each of the three alternative simulations uses a uniform value for hydraulic conductivity. Various heterogeneous arrays of hydraulic-conductivity values were tested, but none showed substantial improvement over simulations with uniform values. Three types of heterogeneity were tested: (1) Increasing the hydraulic conductivity in layer 1 as compared to layer 2; (2) increasing hydraulic conductivity for regions where faults have been identified (Gregory, 1950; Hintze, 1963; Hamilton, 1984; Sargent and Philpott, 1985); and (3) varying hydraulic conductivity by block (keeping it uniform within each of the three blocks).

The first type of heterogeneity was based on previously published laboratory and on-site tests indicating that the upper Navajo aquifer is more permeable than the Lamb Point aquifer (Freethey, 1988, p. 17). The second type of heterogeneity was based on laboratory and on-site tests showing larger values of hydraulic conductivity near fault zones (Freethey, 1988, p. 16). Similarly, the third type of heterogeneity was based on geologic maps and aerial photographs showing that faulting and jointing are more predominant in the western part of the study area (Hamilton, 1984, p. 22). 


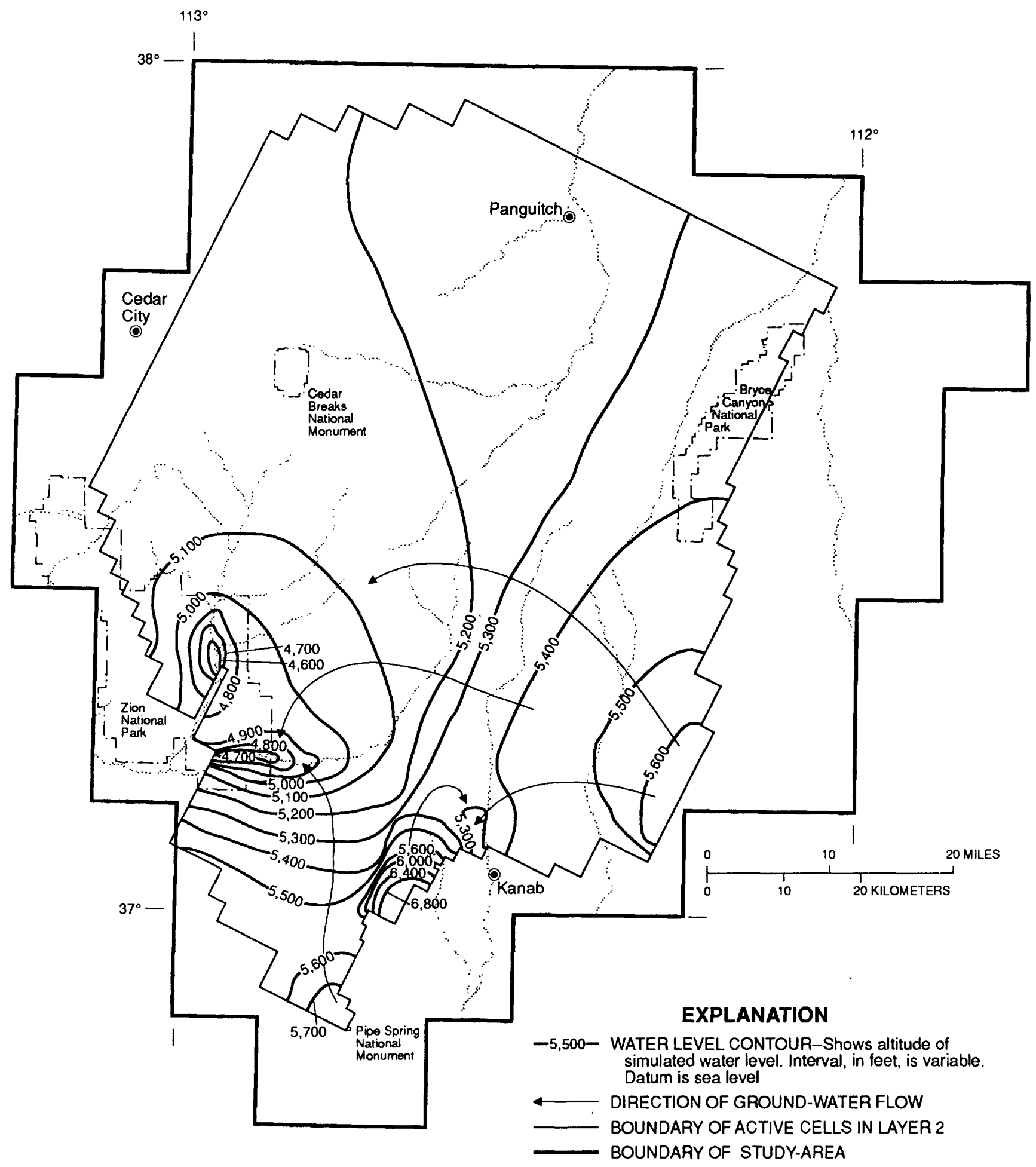

Figure 12.--Steady-state simulated water-level contours in layer 2 for Alternative 1 (unrestricted flow across the Sevier Fault). 


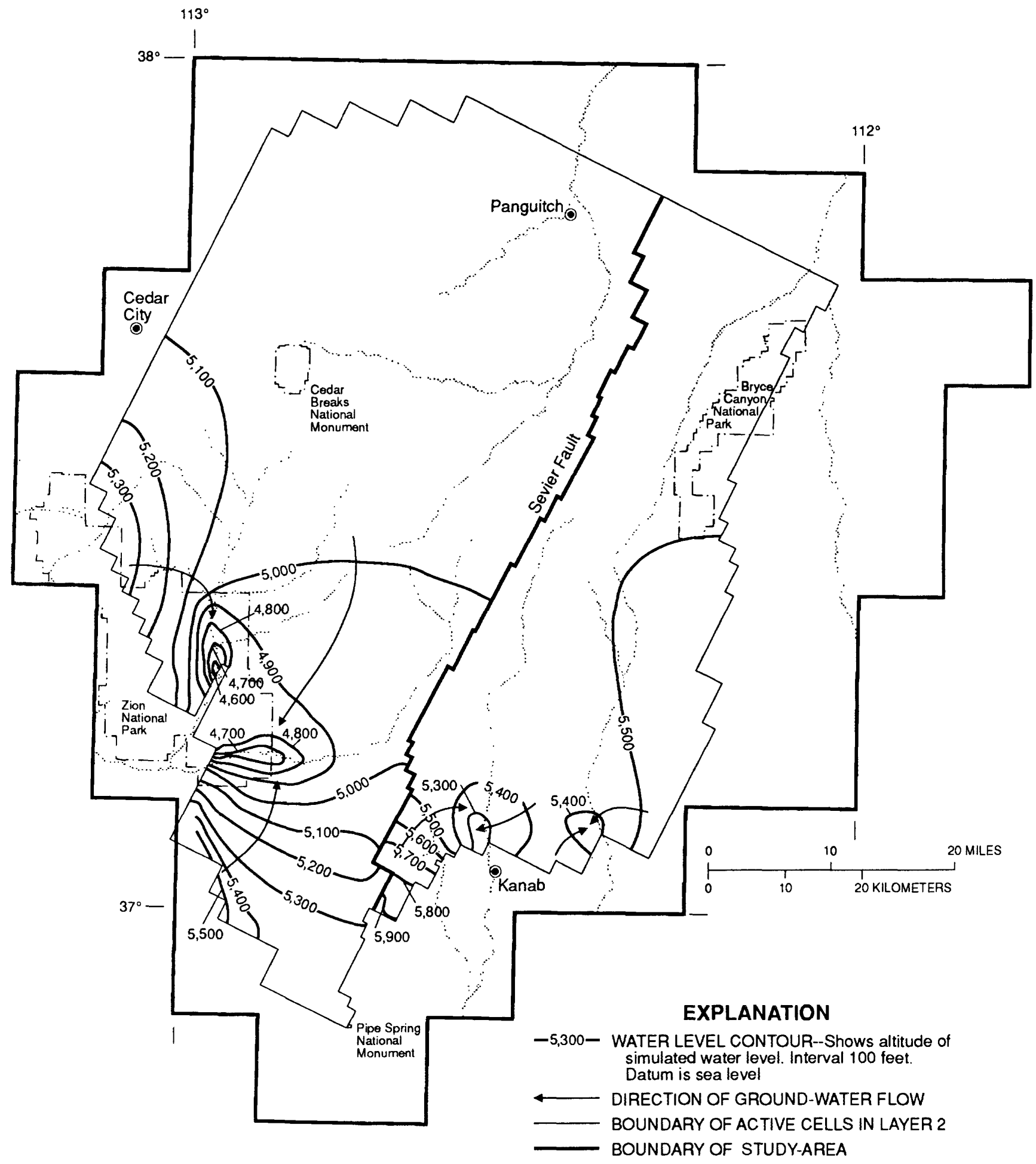

Figure 13.--Steady-state simulated water-level contours in layer 2 for Alternative 2 (no flow across the Sevier Fault). 


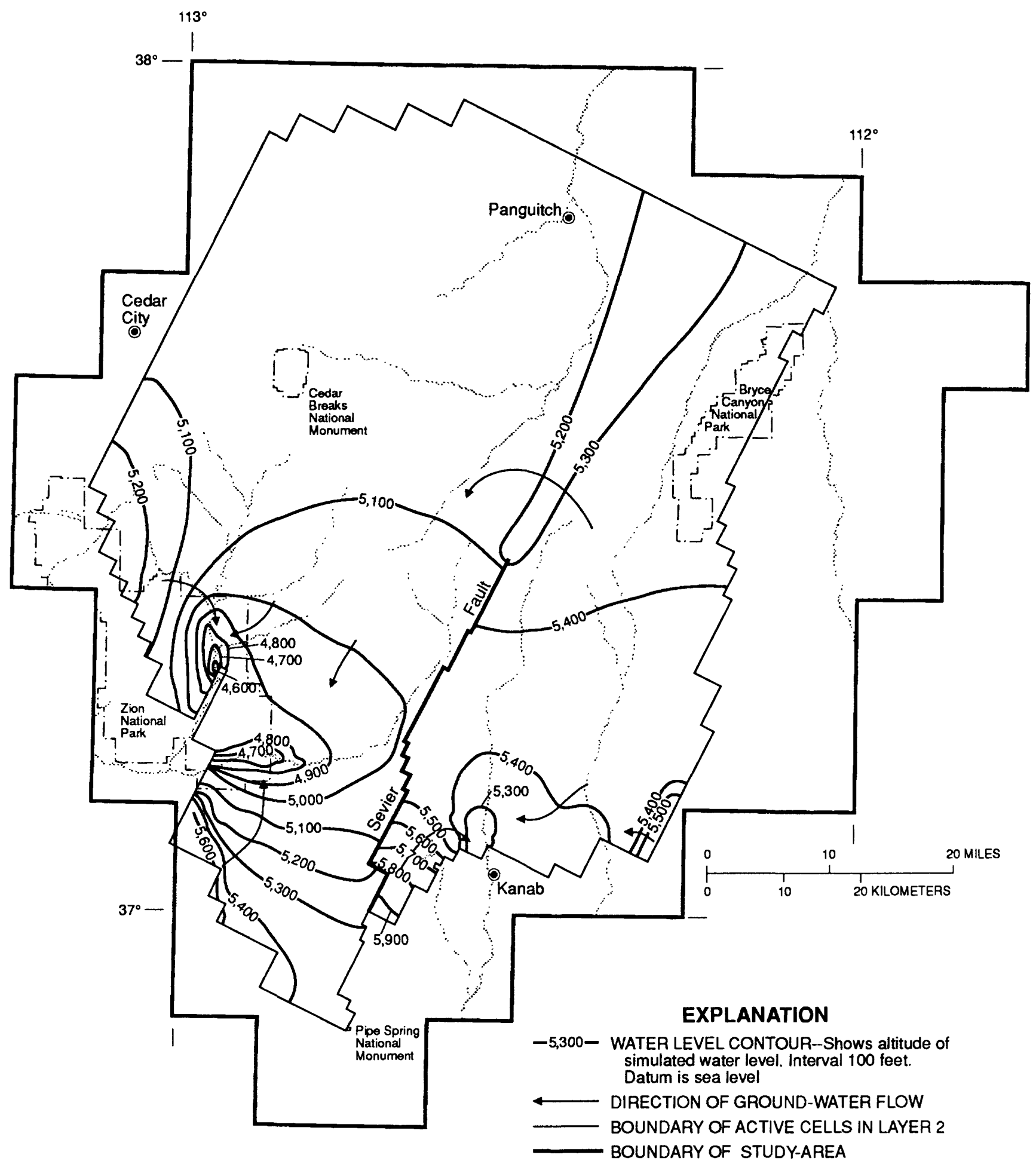

Figure 14.--Steady-state simulated water-level contours in layer 2 for Alternative 3 (partial flow across the Sevier Fault). 
It is assumed that the large size of the study area was the reason why heterogeneous hydraulic-conductivity values did not improve the overall simulation results. Although hydraulic conductivity is known to vary locally, these small-scale variations probably do not affect the rate or direction of movement on a regional scale. Thus, reproducing local heterogeneities within the Navajo aquifer did not significantly improve on simulation results achieved by approximating the Navajo aquifer as a uniform porous medium.

The column-to-row anisotropy factor used for horizontal hydraulic conductivity in all three alternatives (to simulate preferential flow due to jointing) substantially improved results compared to test simulations using isotropic values for hydraulic conductivity. The values of horizontal hydraulic conductivity parallel to the columns (northeast-southwest) were defined as 1.2 times the values parallel to the rows. This anisotropy ratio was based on results of test simulations using column-to-row anisotropy ratios fram $0.5: 1.0$ to 2.0:1.0. The orientation of the columns, however, is more than 30 degrees different from the direction of predominant jointing. Because there are no means of defining principal axes of anisotropy that do not coincide with the row-column orientation of the grid, this anisotropy factor is only a general approximation of the assumed preferential flow along a line oriented north-northwest.

\section{Hypothetical Effects of Withdrawing Ground Water from the Navajo Aquifer}

Possible effects from withdrawing an additional 4,000 acre-ft/yr of ground water over a 30-yr period in layer 1 at Bald Knoll well (C-40-5)2labb-l were simulated in Alternatives 1 through 3. One 30-yr stress period with six 5-year time steps was used for all transient simulations. Both the smallest and largest reported values of storage coefficient and specific yield were used to evaluate the minimum and maximum possible water-level declines for each case. The smallest values were $9.0 \times 10^{-4}$ for storage coefficient and 5 percent for specific yield. The largest values were $2.4 \times 10^{-3}$ for storage oofficient and 10 percent for specific yield.

The results of the additional withdrawals for Alternatives 1, 2, and 3 are shown in table 4. Water-level declines at Bald Knoll were largest for Alternative 1 (unrestricted flow across the Sevier Fault): $188 \mathrm{ft}$ with the smallest storage values and $173 \mathrm{ft}$ with the largest storage values. Waterlevel declines were smallest for Alternative 2 (no flow across the Sevier Fault): $130 \mathrm{ft}$ with the smallest storage values and $119 \mathrm{ft}$ with the largest storage values. Water-level declines were slightly larger for Alternative 3 (flow across only the northern one-half of the Sevier Fault): $135 \mathrm{ft}$ with the smallest storage values and $124 \mathrm{ft}$ with the largest storage values. Waterlevel declines at Bald Knoll were larger for Alternative 1 because this simulation used $1.5 \mathrm{ft} / \mathrm{d}$ for horizontal hydraulic conductivity whereas the other two alternatives used $2.2 \mathrm{ft} / \mathrm{d}$. For each alternative, the smallest storage values yielded larger water-level declines because less water was available for withdrawal per unit volume of aquifer material. 
Table 4.-Ground-Water budgets, flow across major faults, and water-level declines at Bald Knoll for the three alternative simulations using the smallest and the largest storage values for each simulation of hypothetical withdrawals near Bald Knoll

\begin{tabular}{|c|c|c|c|c|c|c|}
\hline & \multicolumn{2}{|c|}{ Altemative 1} & \multicolumn{2}{|c|}{ Alternative 2} & \multicolumn{2}{|c|}{ Alternative 3} \\
\hline & $\begin{array}{l}\text { Smallest } \\
\text { storage } \\
\text { values }\end{array}$ & $\begin{array}{l}\text { Largest } \\
\text { storage } \\
\text { values }\end{array}$ & $\begin{array}{l}\text { Smallest } \\
\text { storage } \\
\text { values }\end{array}$ & $\begin{array}{l}\text { Largest } \\
\text { storage } \\
\text { values }\end{array}$ & $\begin{array}{l}\text { Smailest } \\
\text { storage } \\
\text { values }\end{array}$ & $\begin{array}{l}\text { Largest } \\
\text { storage } \\
\text { values }\end{array}$ \\
\hline \multicolumn{7}{|l|}{ Recharge (acre-feet per year) } \\
\hline $\begin{array}{l}\text { 1. Recharge by precipitation to the } \\
\text { outcrop }\end{array}$ & 56,490 & 56,490 & 55,280 & 55,280 & 55,110 & 55,110 \\
\hline 2. Recharge from streams & 1,540 & 1,540 & 1,820 & 1,820 & 1,660 & 1,660 \\
\hline 3. Recharge from storage & 3,940 & 3,990 & 3,940 & 3,990 & 3,930 & 3,950 \\
\hline Total recharge: & 61,970 & 62,020 & 61,040 & 61,090 & 60,700 & 60,720 \\
\hline \multicolumn{7}{|l|}{ Discharge (acre-feet per year) } \\
\hline 1. Discharge to streams & 44,110 & 44,150 & 49,640 & 49,690 & 49,880 & 49,930 \\
\hline 2. Discharge to springs & 12,990 & 13,030 & 6,530 & 6,560 & 5,990 & 6,010 \\
\hline 3. Well withdrawals & 4,880 & 4,880 & 4,880 & 4,880 & 4,880 & 4,880 \\
\hline Total discharge: & 61,980 & 62,060 & 61,050 & 61,130 & 60,750 & 60,820 \\
\hline \multicolumn{7}{|l|}{ Flow across faults (acre-feet per year) } \\
\hline 1. Sevier Fault (east to west) & 9,810 & 9,910 & 0 & 0 & 3,860 & 3,900 \\
\hline $\begin{array}{l}\text { 2. Paunsaugunt Fault: } \\
\text { a) East to west } \\
\text { b) West to east }\end{array}$ & $\begin{array}{r}4,540 \\
-760 \\
\end{array}$ & $\begin{array}{r}4,370 \\
780 \\
\end{array}$ & $\begin{array}{r}1,570 \\
690 \\
\end{array}$ & $\begin{array}{r}1,460 \\
850 \\
\end{array}$ & $\begin{array}{r}3,080 \\
610 \\
\end{array}$ & $\begin{array}{r}2,870 \\
640 \\
\end{array}$ \\
\hline $\begin{array}{l}\text { Net east to west flow } \\
\text { (across Paunsaugunt Fault) }\end{array}$ & 3,780 & 3,590 & 880 & 610 & 2,470 & 2,230 \\
\hline $\begin{array}{l}\text { Water-level declines at } \\
\text { Bald Knoll (feet) }\end{array}$ & 188 & 173 & 130 & 119 & 135 & 124 \\
\hline
\end{tabular}


The size and shape of the simulated cone of depression produced by withdrawals is one way of assessing impacts on springs in the study area. Because the conditions simulated in Alternative 3 resulted in the best overall comparison between measured and simulated water levels, Alternative 3 is used for a demonstration of water-level declines (figs. 15, 16, 17, and 18). In the simulations that used the small storage values, some of the springs in upper Kanab Canyon and upper Johnson Canyon were affected slightly because the 1- and 2-foot lines of equal water-level decline encompass a few of these springs (figs. 15 and 16). Springs in Zion National Park and Pipe Spring National Monument were not affected in this simulation.

Water-level decline contours for Alternative 1 (not shown) are similar to Alternative 3 except that (1) Larger water-level declines occur near Bald Knoll because of the smaller hydraulic-conductivity values used in both layers in Alternative 1 ; and (2) the 1 - and 2-ft water-level decline contours extend farther into the Zion block but are still far removed from $\mathrm{Zion}$ National Park and Pipe Spring National Monument. Water-level decline contours for Alternative 2 (not shown) are also similar to Alternative 3 except that (1) No water-level decline occurs at all within the Zion block; and (2) within the Kanab and Paria blocks, the 1-, 2-, and 5-ft water-level decline contours are more widespread than in either Alternative 1 or 3. Because of their large distances from the proposed pumping site at Bald Knoll, no substantial waterlevel declines occurred in the vicinity of Zion National Park or Pipe Spring National Monument in any of the simulations. Simulated water-level declines in the Navajo aquifer at Bryce Canyon National Park ranged from 1 to $5 \mathrm{ft}$.

Simulated withdrawals near Bald knoll also caused changes in the quantity of flow crossing the major faults. For Alternative 1, net east-to-west flow across the Sevier Fault was simulated to be 10,010 acre-ft/yr without additional withdrawals (table 3) and between 9,810 (smallest storage) and 9,910 acre-ft/yr (largest storage) with additional withdrawals (table 4). Net eastto-west flow across the Paunsaugunt Fault was simulated to be 3,380 acre-ft/yr without additional withdrawals (table 3) and between 3,780 (smallest storage) and 3,590 acre-ft/yr (largest storage) with additional withdrawals (table 4). For Alternative 2, there was no simulated flow across the Sevier Fault. Net east-to-west flow across the Paunsaugunt Fault was simulated to be 270 acre$\mathrm{ft} / \mathrm{yr}$ without additional withdrawals (table 3 ) and between 880 (smallest storage) and 610 acre-ft/yr (largest storage) with additional withdrawals (table 4). For Alternative 3, net east-to-west flow across the sevier Fault was simulated to be 3,920 acre-ft/yr without additional withdrawals (table 3 ) and between 3,860 (smallest storage) and 3,900 acre-ft/yr (largest storage) with additional withdrawals (table 4). Net east-to-west flow across the Paunsaugunt Fault was simulated to be 1,980 acre-ft/yr without additional withdrawals (table 3) and between 2,470 (smallest storage) and 2,230 acre-ft/yr (largest storage) with additional withdrawals (table 4). 


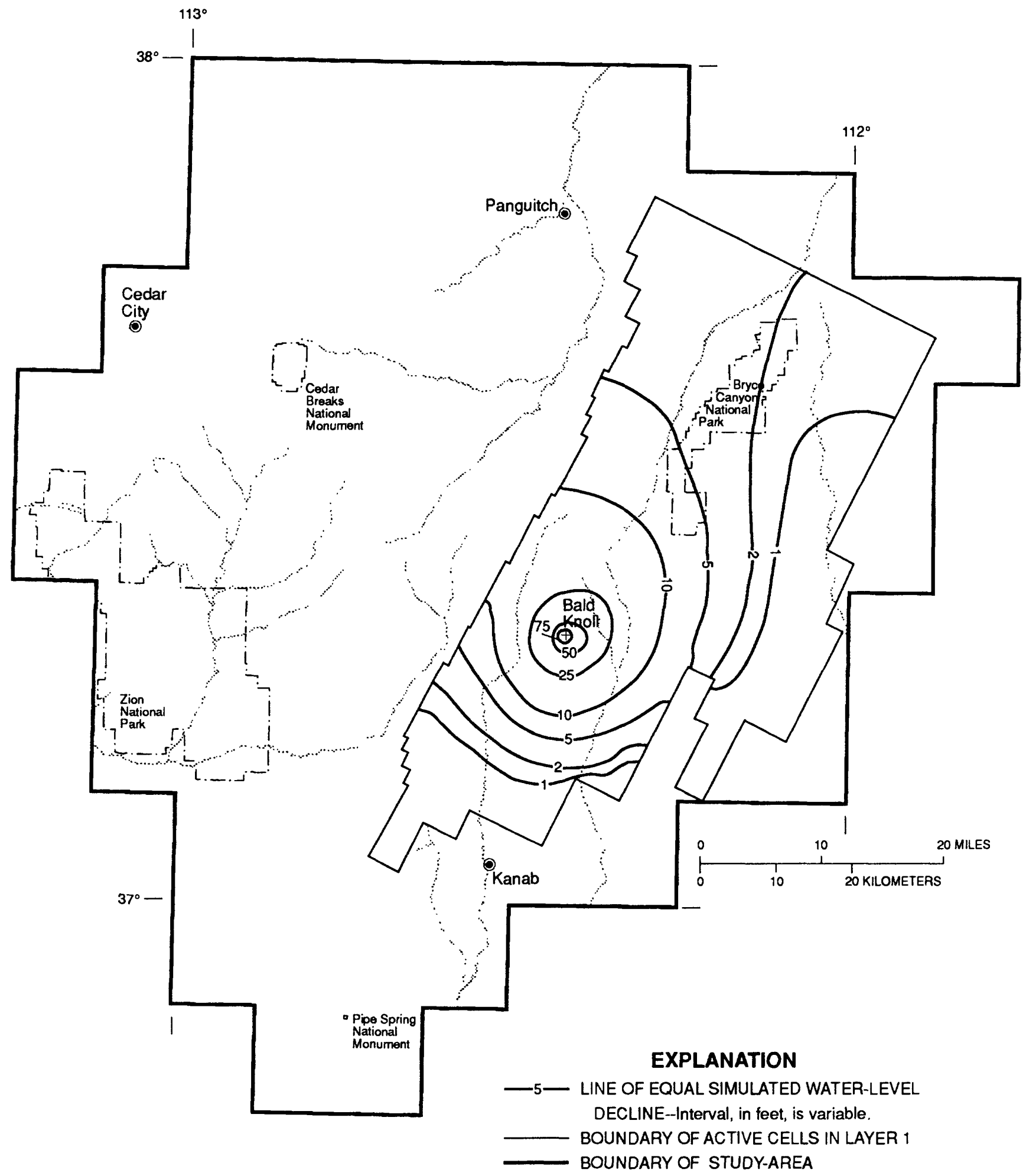

Figure 15.--Water-level declines in layer 1 after 30 years of simulated pumping of 4,000 acre-feet per year near Bald Knoll using smallest estimated storage values (Alternative 3 ). 


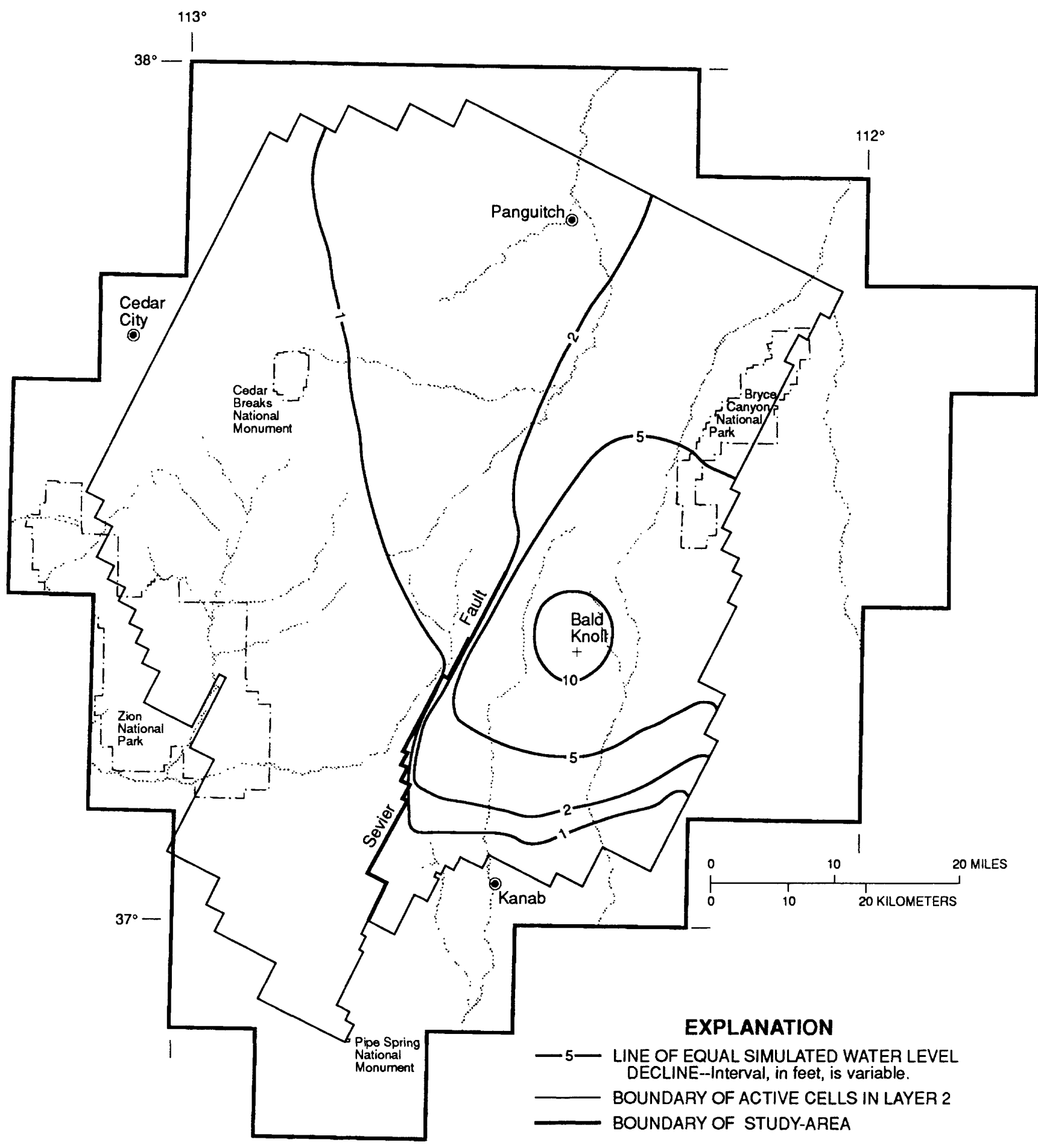

Figure 16.--Water-level declines in layer 2 after 30 years of simulated pumping of 4,000 acre-feet per year near Bald Knoll using smallest estimated storage values (Alternative 3 ). 


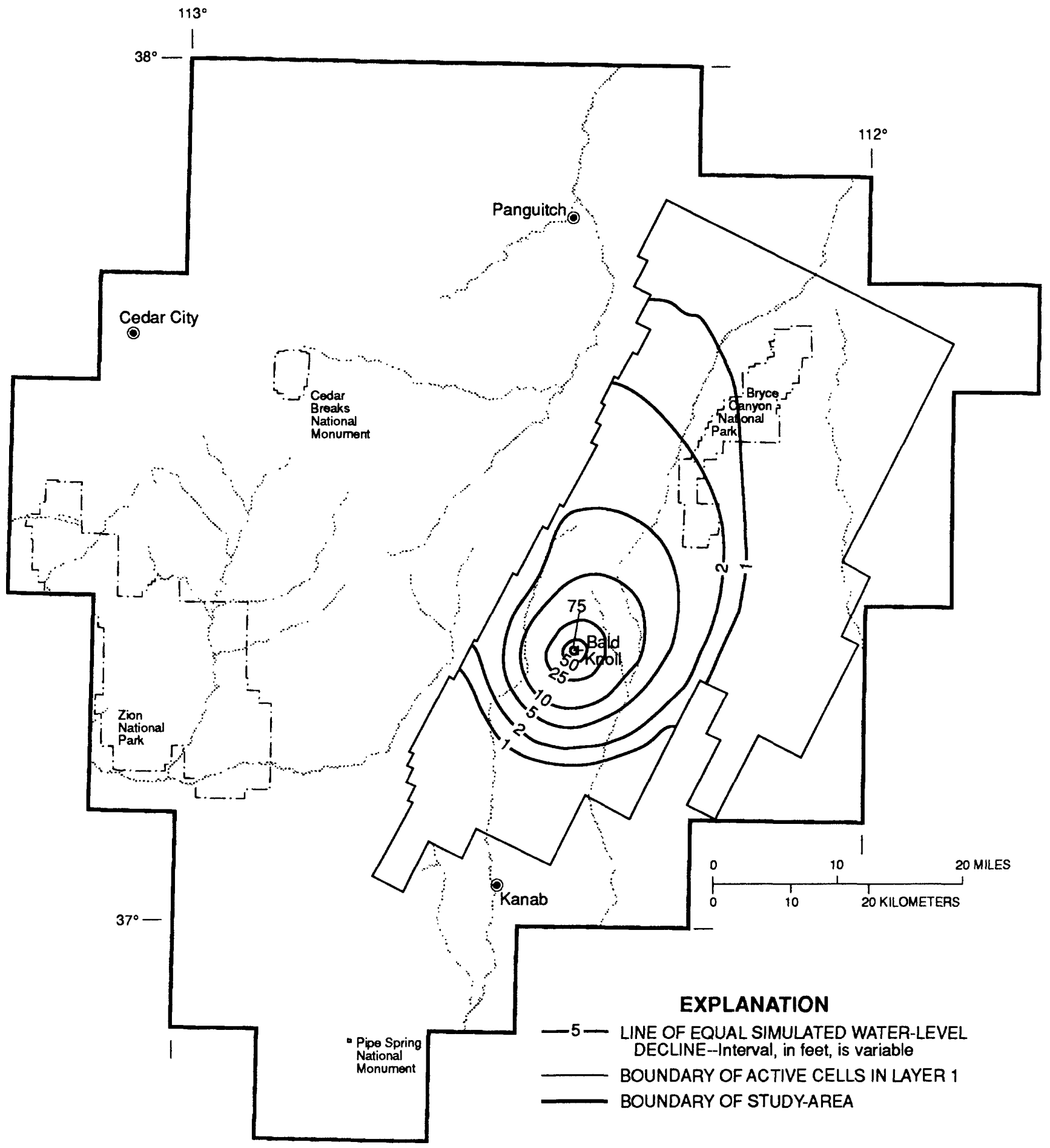

Figure 17.--Water-level declines in layer 1 after 30 years of simulated pumping of 4,000 acre-feet per year near Bald Knoll using largest estimated storage values (Alternative 3). 


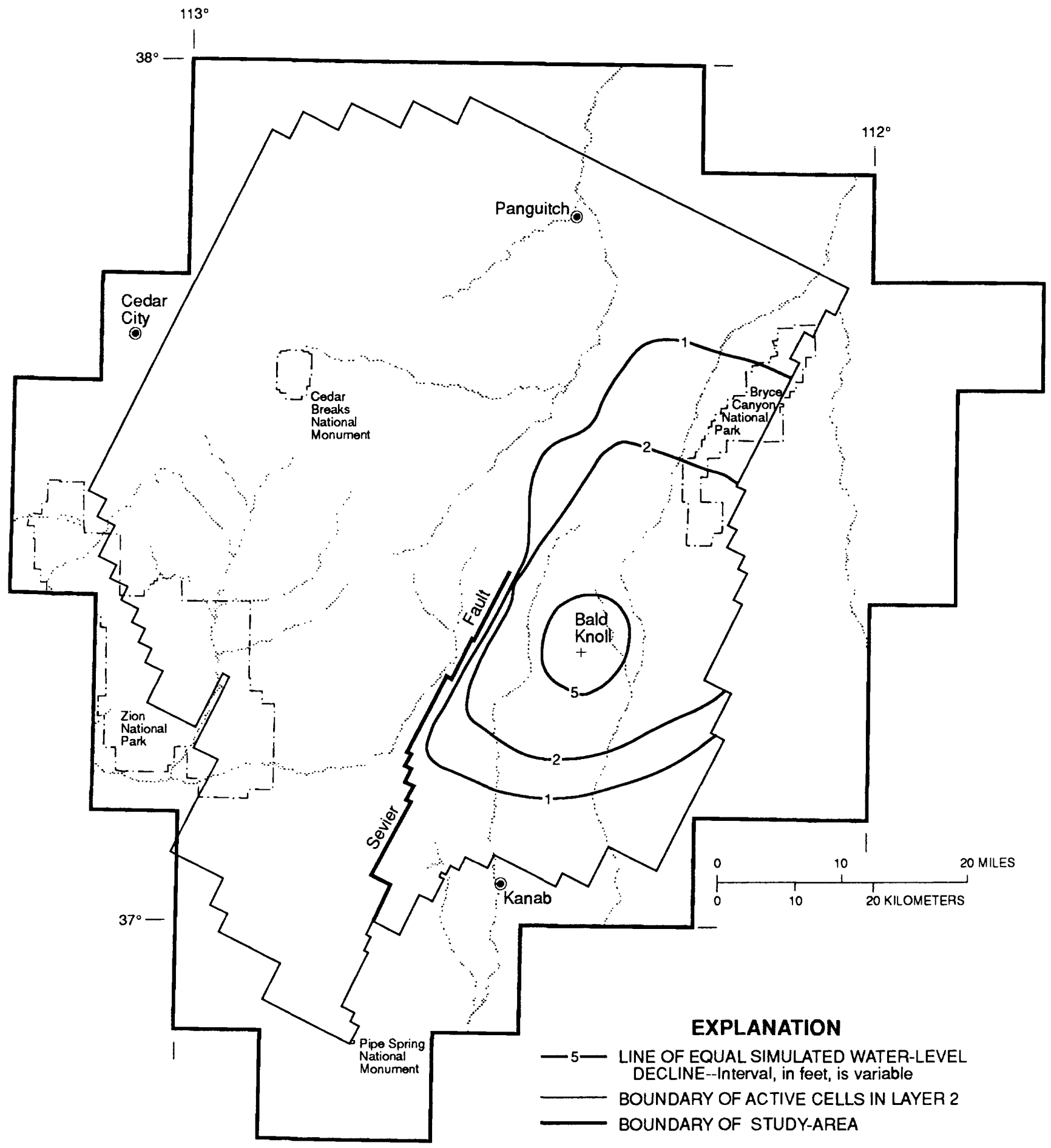

Figure 18.--Water-level declines in layer 2 after 30 years of simulated pumping of 4,000 acre-feet per year near Bald Knoll using largest estimated storage values (Alternative 3 ). 


\section{SUGGESTIONS FOR FURTHER STUDY}

This study is only a preliminary investigation into alternative concepts of ground-water flow within the Navajo aquifer. More hydrologic data are needed to determine the exact rates and directions of ground-water flow within this aquifer. Freethey (1988, p. 36, 38) outlined ten areas where additional data collection is needed. In addition, the following actions might be considered:

1. Obtain a complete inventory of the springs in the Zion block, within and outside the boundaries of Zion National Park, during the dormant period of phreatophyte growth. Partial spring surveys have been conducted over the past 54 years, but there has never been a complete survey for the entire area during the winter season when the effects of evapotranspiration are minimal.

2. Conduct several seepage studies along the North and East Forks Virgin River, Kanab Creek, and the Paria River. These seepage studies need to include all reaches where these rivers transect the Navajo Sandstone outcrop. The studies need to be conducted during the dormant period of phreatophyte growth in order to refine the locations and quantities of seepage between the aquifer and these streams.

3. Drill a pair of wells straddling the Sevier Fault south of the White Cliffs where the Navajo Sandstone is exposed. Determine the degree of hydraulic connection across the fault by pumping one well while measuring water-level changes in the other.

4. Drill wells into the underlying Kayenta Formation in areas where the rock is fractured and in areas where it is unfractured. Measure water levels and conduct aquifer tests to obtain vertical hydraulic conductivity and determine the rate of vertical ground-water movement.

5. Drill pairs of observation wells screened in the Carmel Formation and the upper (or undifferentiated) part of the Navajo Sandstone in areas where the Carmel Formation is fractured and in areas where it is unfractured to determine if the Navajo aquifer is being recharged from the overlying Carmel Formation. Perform aquifer tests to determine vertical hydraulic-conductivity values of the Carmel confining unit.

\section{SUMMARY}

The Navajo aquifer west of the Paria River drainage and east of the Hurricane Fault in southwestern Utah and northwestern Arizona was studied using computer simulation to examine the potential effects of additional ground-water withdrawals. The region is semiarid, and normal annual precipitation ranges from 10 to 40 in. Within the study area, the Navajo Sandstone has a fairly uniform 2,000-ft thickness. In the central part of the study area, the Navajo aquifer is divided into two separate water-bearing units by the Tenney Canyon confining unit. Elsewhere, the Navajo aquifer remains undivided. In the southern part of the study area, $790 \mathrm{mi}^{2}$ of the Navajo Sandstone crops out. Farther north, the sandstone is deeply buried as it dips 1 to 5 degrees to the north-northeast. The geometry of the Navajo aquifer is complicated by the large vertical offsets of the Sevier and Paunsaugunt Faults. Also, a joint 
pattern is present throughout the study area, but it is most pronounced in the western section near $\mathrm{Z}$ ion National Park where the predominant orientation is north-northwest. These fractures, if open, may cause anisotropic flow conditions.

The hydrologic boundaries of the Navajo aquifer are well defined to the south, west, and east, but are poorly defined to the north. To the south, southeast, and west, the hydrologic boundaries are the erosional limits of the Navajo Sandstone. To the northeast, the Paria River likely recharges the Navajo aquifer where the river is higher than the water level in the aquifer and likely discharges to the river where the river is lower than the water level in the aquifer. The northern boundary is not clearly defined because the Navajo Sandstone is deeply buried there. It is assumed that little groundwater movement occurs in the northern area because the potentiometric surface is assumed to be nearly flat. Vertical flow to or from the Navajo aquifer is assumed to be restricted because of the confining nature of both the underlying Kayenta Formation and the overlying Carmel Formation.

Hydrologic properties of the aquifer and confining units have been estimated or measured and are reported in previous investigations. Reported values for horizontal hydraulic conductivity range from 0.002 to $6.1 \mathrm{ft} / \mathrm{d}$ for the Navajo aquifer. Vertical hydraulic-conductivity values range from 0.005 to $5.0 \mathrm{ft} / \mathrm{d}$. The vertical hydraulic conductivity of the Tenney Canyon confining unit was reported as 0.0052 to $0.42 \mathrm{ft} / \mathrm{d}$ based on an aquifer test. The larger values of hydraulic conductivity have been correlated with fractured-rock zones, which are thought to transmit water more readily than unfractured-rock zones. The hydrologic properties of the deformed rock along major faults is largely unknown.

Saturated thickness of the Navajo aquifer is about 1,700 ft at Bald Knoll. North of Bald Knoll, it is assumed that the aquifer is confined and fully saturated. If this assumption is correct, saturated thickness would be about $2,000 \mathrm{ft}$.

Local ground-water movement in the areas of exposed Navajo Sandstone is better defined than either regional flow across the sevier and Paunsaugunt Faults or movement farther north where the Navajo aquifer is deeply buried. The main source of recharge for the Navajo aquifer is infiltration of precipitation on the outcrop. Approximately 550,000 acre-ft of precipitation falls annually on the outcrop within the study area. On the basis of estimates of discharge from the Navajo aquifer, 50,280 to 68,180 acre-feet of water recharges the Navajo aquifer annually.

Most of the water that enters the Navajo aquifer at the outcrop area moves toward nearby deeply incised canyons where it is discharged to streams and springs. Estimates based on stream seepage studies and records from long-term stream discharge stations indicate that between 39,800 and 57,700 acre-ft/yr of ground water discharges from the Navajo aquifer to the East and North Forks Virgin River and Kanab Creek. The quantity of water discharging into the Paria River is unknown. Total spring discharge throughout the study area is estimated to be 8,140 acre-ft/yr. Evapotranspiration and well withdrawals discharge less than 2,400 acre-ft/yr (assuming no major evapotranspiration losses occur in the Zion and Paria blocks), which is relatively small compared to the other camponents of discharge. 
As part of the study, three-dimensional, finite-difference computer simulations were used to test various concepts of the hydrologic system. The aquifer geometry was represented by a two-layered model consisting of three separate blocks. Alternative simulations were developed in which horizontal hydraulic conductivity varied and the Sevier Fault was simulated as having (1) unrestricted flow; (2) no flow; and (3) flow across the northern one-half but not across the southern one-half (partial flow).

In trying to approximate measured water levels and ground-water budget components, it became evident that ground-water movement most likely is restricted across the southern part of the Sevier Fault where the Navajo Sandstone is exposed. The arithmetic mean of the differences between measured and simulated water levels was $+43 \mathrm{ft}$ for Alternative $1,+16 \mathrm{ft}$ for Alternative 2 , and $-1 \mathrm{ft}$ for Alternative 3. The simulated steady-state quantity of ground water moving from east to west across the Sevier Fault was 10,010 acre-ft/yr for Alternative 1; 0 acre-ft/yr for Alternative 2; and 3,920 acre-ft/yr for Alternative 3. Net east-to-west ground-water movement across the Paunsaugunt Fault was 3,380 acre-ft/yr for Alternative 1; 270 acre-ft/yr for Alternative 2; and 1,980 acre-ft/yr for Alternative 3.

Withdrawals of 4,000 acre-ft/yr were simulated for a proposed pumping well near Bald Knoll for a 30-yr period in all three alternative simulations. Each alternative was tested with both the smallest and largest reported values for specific yield and storage coefficient. These storage values were from 5 to 10 percent for specific yield and from $9.0 \times 10^{-4}$ to $2.4 \times 10^{-3}$ for the confinedaquifer storage coefficient.

Water-level declines near Bald Knoll ranged from 119 to $188 \mathrm{ft}$. The 119ft water-level decline was simulated using the largest storage coefficients in Alternative 2 and a hydraulic conductivity of $2.2 \mathrm{ft} / \mathrm{d}$. The 188-ft water-level decline was simulated using the smallest storage coefficients in Alternative 1 and a hydraulic conductivity of $1.5 \mathrm{ft} / \mathrm{d}$. Using the smallest reported storage values, water-level declines at Pipe Spring National Monument and Zion National Park after a 30-yr pumping period were less than $1 \mathrm{ft}$. Simulations with larger storage values produced even smaller water-level declines.

For Alternatives 1 and 3, simulated withdrawals also had the effect of slightly increasing flow across the Paunsaugunt Fault and slightly decreasing flow across the Sevier Fault compared to steady-state simulations. For Alternative 2, however, there was a large increase in flow across the Paunsaugunt Fault due to pumping, probably because no ground water moves across the Sevier Fault in this simulation. 


\section{REFERENCES CITED}

Bedient, P.B., and Huber, W.C., 1988, Hydrology and floodplain analysis: Reading, Massachusetts, Addison-Wesley Publishing Company, 650 p.

Bingham Engineering, 1981, Alton coal project, 1980-81 groundwater investigation, Part 1, Test drilling and pumping data at Bald Knoll: Salt Lake City, Utah, May 1981, 30 p.

1987, Alton coal project, Navajo aquifer investigation: Prepared for Utah International by Bingham Engineering, Salt Lake City, Utah, 93 p., 8 appendices.

Blanchard, P.J., 1986, Ground-water conditions in the Kaiparowits Plateau area, Utah and Arizona, with emphasis on the Navajo Sandstone: Utah Department of Natural Resources Technical Publication 81, 87 p.

Camp Dresser and McKee Inc., 1987, Alton coal project quarterly hydrology report July 1987 - September 1987: Denver, Colorado, December 1987.

- 1988a, Alton coal project baseline data updates through June 1987: Denver, Colorado, January 1988.

- -1988b, Alton coal project quarterly hydrology report October 1987 Decenber 1987: Denver, Colorado, February 1988.

1988c, Alton coal project quarterly hydrology report January 1988 - March 1988: Denver, Colorado, May 1988.

Cordova, R.M., 1981, Ground-water conditions in the upper Virgin River and Kanab Creek basins area, Utah, with emphasis on the Navajo Sandstone: Utah Department of Natural Resources Technical Publication 70, 87 p.

Danielson, T.W., and Hood, J.W., 1984, Infiltration to the Navajo Sandstone in the lower Dirty Devil River basin, Utah, with emphasis on techniques used in its determination: U.S. Geological Survey water-Resources Investigations Report 84-4154, 45 p.

Doelling, H.H., and Graham, R.L., 1972, Southwestern Utah coal fields; Alton, Kaiparowits Plateau, and Kolob-Harmony: Utah Geological and Mineralogical Survey Monograph Series 1, 333 p.

Fenneman, N.M., 1931, Physiography of western United States: New York, MoGrawHill, $534 \mathrm{p}$.

Freethey, G.W., 1988, Geohydrology of the Navajo Sandstone in western Kane, southwestern Garfield, and southeastern Iron Counties, Utah: U.S. Geological Survey Water-Resources Investigations Report 88-4040, 43 p.

Goode, H.D., 1966, Second reconnaissance of water resources in western Kane County, Utah: Utah Geological and Mineralogical Survey Water-Resources Bulletin 8, 44 p. 
Gregory, H.E., 1932, Geology of the Pine Creek tunnel: unpublished report, National Park Service.

- -1950, Geology and geography of the Zion Park region, Utah and Arizona: U.S. Geological Survey Professional Paper 220, 200 p.

Hamilton, W.L., 1984, The sculpturing of Zion: Springdale, Utah, Zion National Park History Association, 132 p.

--1987, Geologic map of Zion National Park, Utah: Zion Natural History Association, scale $1: 31,680$.

Hintze, L.F., 1963, Geologic map of southwestern Utah, in Guidebook to the geology of southwestern Utah: Intermountain Association of Petroleum Geologists, scale 1:250,000.

Hood, J.W., and Danielson, T.W., 1979, Aquifer tests of the Navajo Sandstone near Caineville, Wayne County, Utah: Utah Department of Natural Resources Technical Publication 66, 69 p.

Hooper, D., and Schwarting, R., 1981, Water-use data for public suppliers in Utah, 1979: Utah Department of Natural Resources, Utah Water-Use Report $2,80 \mathrm{p}$.

--1982a, Water-use data for public suppliers in Utah, 1980: Utah Department of Natural Resources, Utah Water-Use Report 3, 94 p.

--1982b, Water-use data for public suppliers in Utah, 1981: Utah Department of Natural Resources, Utah Water-Use Report 4, 97 p.

Johnson, B., Hooper, D., Jackson, S., and Schwarting, R., 1985, Water-use data for public water suppliers and self-supplied industry, 1982 and 1983: Utah Department of Natural Resources, Utah Water-Use Report 5, 137 p.

Johnson, B., Jackson, S., and Schwarting, R., 1988, Water-use data for public water suppliers and self-supplied industry, 1984 and 1985: Utah Department of Natural Resources, Utah Water-Use Report 6, 131 p.

Lohman, S.W., and others, 1972, Definitions of selected ground-water terms-Revisions and concptual refinements: U.S. Geological Survey Water Supply Paper 1988, $21 \mathrm{p}$.

McDonald, M.G., and Harbaugh, A. W., 1988, A modular three-dimensional finitedifference ground-water flow model: U.S. Geological Survey Techniques of Water-Resources Investigations, book 6, chap. Al, 528 p.

Neuman, S.P., and Witherspoon, P.A., 1972, Field determination of the hydraulic properties of leaky multiple aquifer systems: Water Resources Research, v. 8, no. 5, p. 1284-1298.

Sargent, K.A., and Philpott, B.C., 1985, Geologic map of the Johnson quadrangle, Kane County, Utah, and Coconino County, Arizona: U.S. Geological Survey Geologic Quadrangle Map GQ-1602, scale 1:62,500, 1 sheet. 
Todd, D.K., 1987, Alton coal slurry pipeline project, simulation of water supply development, Kane County, Utah: Berkeley, California, David Keith Todd Consulting Engineers, Inc., 39 p., 2 appendices.

Uygur, Kadir, 1980, Hydraulic and petrographic characteristics of the Navajo Sandstone in southern Utah: Salt Lake City, University of Utah, Department of Geology and Geophysics, Master's Thesis, 134 p.

Utah Geological and Mineral Survey, 1983, Energy resources map of Utah: Utah Department of Natural Resources Map 68, scale 1:500,000.

U.S. Weather Bureau, 1963a, Normal annual and May - September precipitation (1931-1960) for the State of Utah: Map of Utah, scale 1:500,000, 1 sheet.

-1963b, Normal annual and October - April precipitation (1931-1960) for the State of Utah: Map of Utah, scale 1:500,000, I sheet.

- -1963c, Normal annual and October - April precipitation (1931-1960) for the State of Arizona: Map of Arizona, scale 1:500,000, 1 sheet.

Wilson, E.D., Moore, R.T., and Cooper, J.R., 1969, Geologic map of Arizona: Arizona Bureau of Mines, U.S. Geological Survey, scale 1:500,000. 